PNNL-13282

\title{
Groundwater Quality Assessment for Waste Management Area U: First Determination
}

\author{
F. N. Hodges \\ C. J. Chou
}

July 2000

Prepared for the U.S. Department of Energy under Contract DE-AC06-76RLO 1830

Pacific Northwest National Laboratory

Richland, Washington 99352 


\section{Summary}

Waste Management Area U (WMA U) is located in the 200 West Area of the Hanford Site. The area includes the U Tank Farm, which contains 16 single-shell tanks and their ancillary equipment and waste systems. WMA $U$ is regulated under the Resource Conservation and Recovery Act of 1976 (RCRA) as stipulated in $40 \mathrm{CFR}$ Part 265, Subpart F, which is incorporated into the Washington State dangerous waste regulations (WAC 173-303-400) by reference.

Groundwater monitoring at WMA $U$ has been guided by an interim status indicator evaluation program. As a result of changes in the direction of groundwater flow, background values for the WMA have been recalculated several times during its monitoring history. The most recent recalculation revealed that one of the indicator parameters, specific conductance, exceeded its background value in downgradient well 299-W19-41. This triggered a change from detection monitoring to a groundwater quality assessment program. The major contributors to the higher specific conductance are nonhazardous constituents, such as bicarbonate, calcium, chloride, magnesium, sodium, and sulfate. Chromium, nitrate, and technetium-99 are present and are increasing; however, they are significantly below their drinking water standards.

The objective of this study is to determine whether the increased concentrations of chromium, nitrate, and technetium-99 in groundwater are from WMA U or from an upgradient source. Interpretation of groundwater monitoring data indicates that both the nonhazardous constituents causing elevated specific conductance in groundwater and the tank waste constituents present in groundwater at the WMA are a result of surface water infiltration in the southern portion of the WMA. There is evidence that both upgradient and WMA sources contribute to the nitrate concentrations that were detected. There is no indication of an upgradient source for the chromium and technetium- 99 that was detected. Therefore, a source of contamination appears to reside in the southern portion of WMA U. 


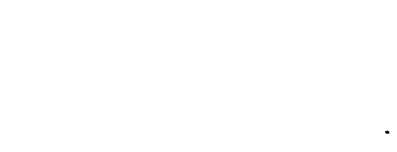




\section{DISCLAIMER}

Portions of this document may be illegible in electronic image products. Images are produced from the best available original document. 


\section{DISCLAIMER}

This report was prepared as an account of work sponsored by an agency of the United States Government. Neither the United States Government nor any agency thereof, nor any of their employees, make any warranty, express or implied, or assumes any legal liability or responsibility for the accuracy, completeness, or usefulness of any information, apparatus, product, or process disclosed, or represents that its use would not infringe privately owned rights. Reference herein to any specific commercial product, process, or service by trade name, trademark, manufacturer, or otherwise does not necessarily constitute or imply its endorsement, recommendation, or favoring by the United States Government or any agency thereof. The views and opinions of authors expressed herein do not necessarily state or reflect those of the United States Government or any agency thereof. 


\section{Contents}

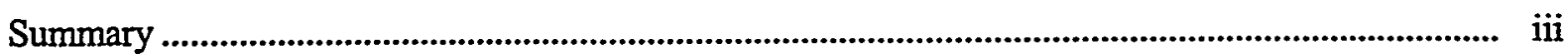

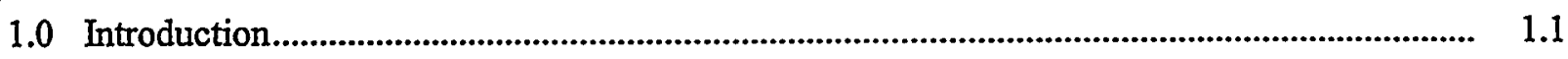

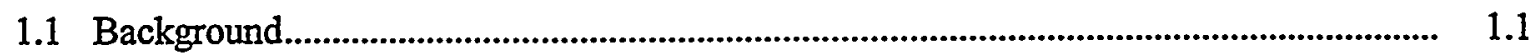

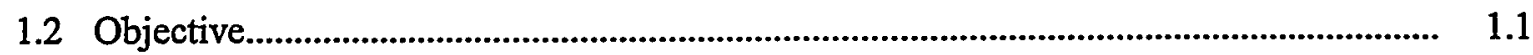

2.0 Facility Description and Waste Characteristics ................................................................ 2.1

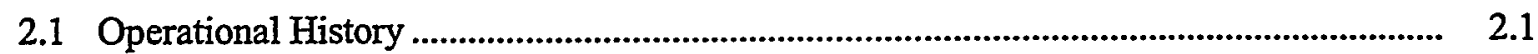

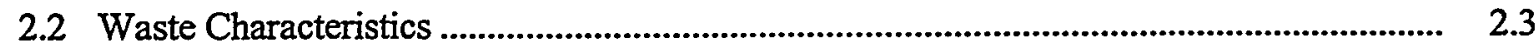

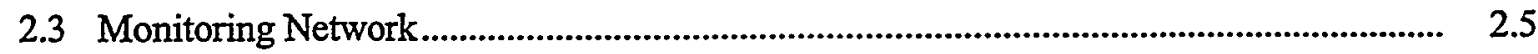

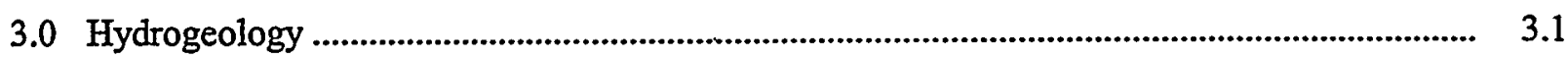

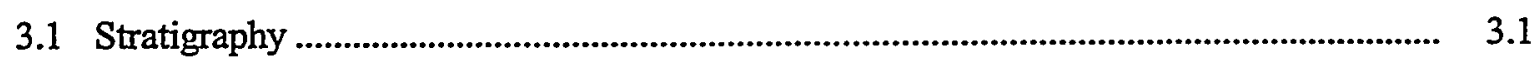

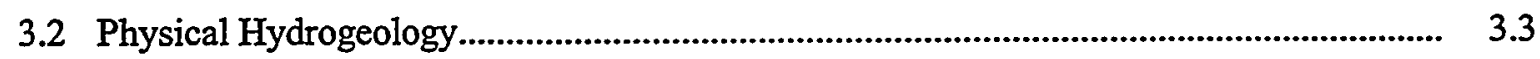

4.0 Summary of Groundwater Monitoring Results.............................................................. 4.1

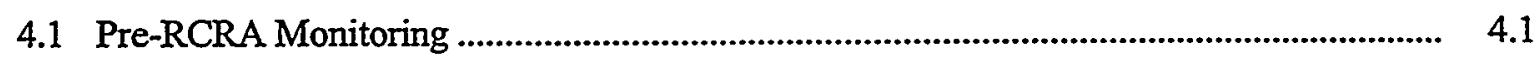

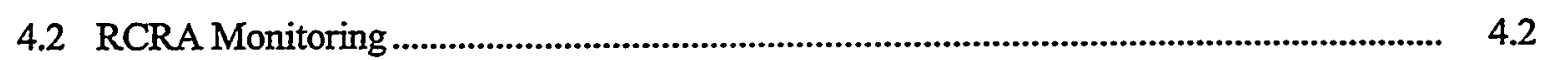

4.2.1 Specific Conductance ..................................................................................... 4.4

4.2.2 Total Organic Halides...................................................................................... 4.4

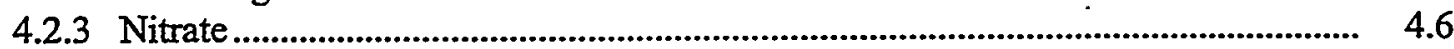

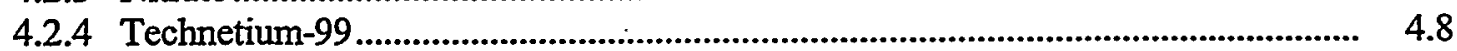

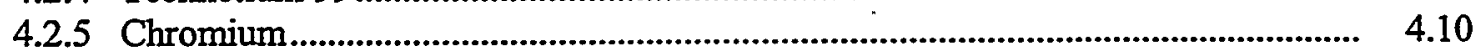

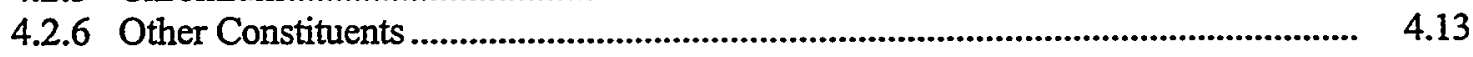

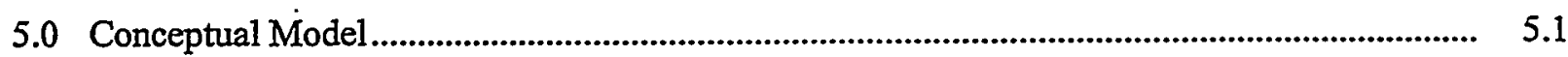

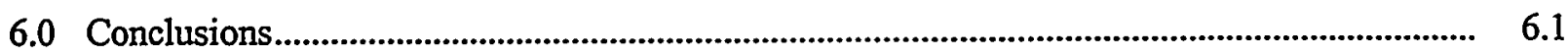

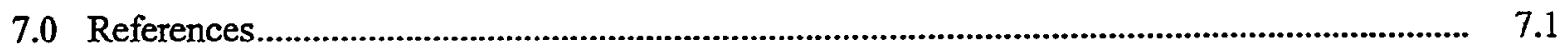




\section{Figures}

1.1 Map Showing Location of Waste Management Area U in the 200 West Area of the Hanford Site

2.1 Map of Waste Management Area U, Showing Locations of Waste Tanks, Monitoring Wells, and Miscellaneous Structures

3.1 Generalized Stratigraphic Column for the Suprabasalt Sediment Beneath the 200 West Area

3.2 Hydrograph for Well 299-W19-1

3.3 Hydrographs for RCRA Monitoring Wells at Waste Management Area U

3.4 Water-Table Map for Vicinity of Waste Management Area U

4.1 Nitrate Concentrations in Pre-RCRA Monitoring Well 299-W19-12

4.2 Technetium-99 and Gross Beta Concentrations in Pre-RCRA Monitoring Well 299-W19-12. 4.2

4.3 Specific Conductance Values for Wells in the WMA U Monitoring Network

4.4 Plot of Nitrate Concentrations in Monitoring Wells at WMA U.

4.5 Plot of Technetium-99 Concentrations for Downgradient Wells at WMA U.

4.6 Plot of Technetium-99 in Upgradient Wells 299-W18-25 and 299-W18-31 and Downgradient Wells 299-W19-31, 299-W19-32, 299-W19-41, and 299-W19-42 .

4.7 Plot of Filtered Chromium Concentrations in (a) Wells 299-W18-25, 299-W18-31, and 299-W18-30, and in (b) Wells 299-W19-12, 299-W19-31, 299-W19-32, 299-W19-41, and 299-W 19-42

4.8 Plots of Filtered Iron, Chromium, Nickel, and Manganese in (a) Upgradient Well 299-W18-25, and (b) Downgradient Well 299-W19-41

4.9 Chloride Concentrations in (a) Wells 299-W19-31, 299-W19-32, 299-W19-41, and 299-W19-42; and in (b) Wells 299-W18-25, 299-W18-31, and 299-W18-30

4.10 Sodium Concentrations in (a) Wells 299-W19-31, 299-W19-32, 299-W19-41, and 299-W19-42; and in (b) Wells 299-W18-25, 299-W18-31, and 299-W18-30

4.11 Calcium Concentrations in (a) Wells 299-W19-31, 299-W19-32, 299-W19-41, and 299-W19-42; and in (b) Wells 299-W18-25, 299-W18-31, and 299-W18-30 
4.12 Sulfate Concentrations in (a) Wells 299-W19-31, 299-W19-32, 299-W19-41, and 299-W19-42; and in (b) Wells 299-W18-25, 299-W18-31, and 299-W18-30

5.1 Soil Pathway Conceptual Model ......................................................................................... 5.2

5.2 Plot of Nitrate/Technetium-99 versus Technetium-99 for Monitoring Wells at WMA U

\section{Tables}

2.1 Selected Waste Constituents and Average Compositions in the Tanks for Waste Management Area U

2.2 Wells in Monitoring Network

4.1. Milliequivalents in Recent Waste Management Area U Groundwater Samples 


\subsection{Introduction}

The Hanford Federal Facility Agreement and Consent Order (commonly known as the Tri-Party Agreement; Ecology et al. 1998) placed the single-shell tank farms under Resource Conservation and Recovery Act of 1976 (RCRA) interim status regulation. The Tri-Party Agreement also placed the interim status sites under the supervision of the Washington State Department of Ecology (Ecology).

Waste Management Area U (WMA U) includes the U Tank Farm, which contains 16 single-shell tanks (constructed in 1943-1944) and their ancillary equipment and waste systems (e.g., transfer lines, diversion boxes). WMA $U$ is located in the 200 West Area (Figure 1.1) and is currently regulated under RCRA interim status regulations as stipulated in 40 CFR Part 265, Subpart F, which is incorporated into the Washington State dangerous waste regulations (WAC 173-303-400) by reference.

\subsection{Background}

A RCRA Part A (interim status) permit application and closure/work plan was submitted in 1989 (DOE 1989). As prescribed under Tri-Party Agreement Major Milestone M-45-00 single-shell tank farm WMAs will be closed in accordance with WAC 173-303-610. The time and method of closure are uncertain, but closure will probably be after 2030 .

Groundwater monitoring has been guided by an interim status indicator evaluation program that compared general contaminant indicator parameters from downgradient wells to background values established from upgradient wells. One of the indicator parameters, specific conductance, exceeded its background value in one downgradient well, 299-W19-41, triggering a change from detection monitoring to a groundwater quality assessment program (Hodges and Chou 2000).

Major contributors to the higher specific conductance are nonhazardous constituents, such as bicarbonate, calcium, chloride, magnesium, sodium and sulfate. However, tank waste constituents chromium, nitrate, and technetium-99 have historically been present in downgradient wells at the WMA and are presently increasing in well 299-W19-41. This report presents the results of an investigation into the relationship between the constituents causing elevated specific conductance in well 299-W19-41 and the tank waste constituents found in that well to determine whether they are a result of an upgradient source outside of WMA U.

\subsection{Objective}

The objective of this study is to determine, as allowed under 40 CFR 265.93(d)(5), whether the increased concentration's of chromium, nitrate, and technetium-99 in groundwater are from WMA U or from an upgradient source. Based on the results of the first determination, if WMA $U$ is not the source of groundwater contamination, then the site will revert to detection monitoring [40 CFR 265.93(d)(6)]. If WMA $U$ is the source, then a second part of the groundwater quality assessment plan will be prepared. 


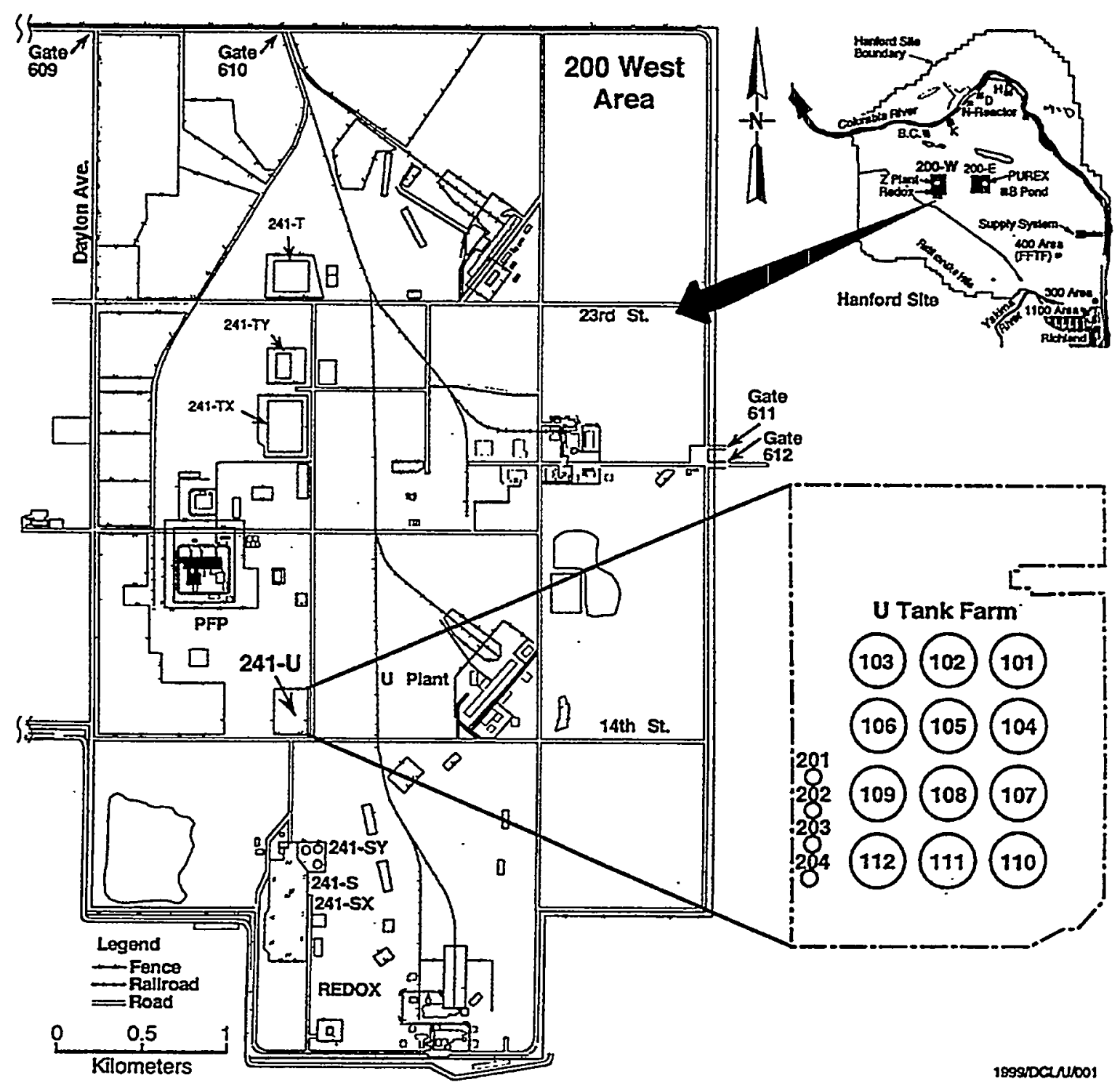

Figure 1.1. Map Showing Location of Waste Management Area U in the 200 West Area of the Hanford Site

In addition to this introduction, this report provides a description of WMA $U$ facilities and the waste disposed there (Chapter 2.0), the hydrogeology of the area (Chapter 3.0), an evaluation of groundwater chemistry at WMA U (Chapter 4.0), a conceptual model for the groundwater observations at WMA U (Chapter 5.0), and conclusions of the study (Chapter 6.0). 


\subsection{Facility Description and Waste Characteristics}

WMA U is located in the south-central portion of the Hanford Site's 200 West Area (see Figure 1.1). The WMA has an area of $30,000 \mathrm{~m}^{2}\left(323,000 \mathrm{ft}^{2}\right)$ and contains 16 single-shell tanks constructed between 1943 and 1944 (Figure 2.1). Twelve of the tanks (U-101 through U-112) have capacities of $2,017,000 \mathrm{~L}(533,000 \mathrm{gal})$ and four (U-201 through U-204) have capacities of $208,000 \mathrm{~L}$ (55,000 gal).

The tanks are constructed with a concrete shell and a single-walled liner of carbon steel. The tanks are $22.9 \mathrm{~m}(75 \mathrm{ft})$ in diameter and are $\sim 9 \mathrm{~m}(29.5 \mathrm{ft})$ in height. The tanks are set with the bottoms $\sim 11 \mathrm{~m}$ ( $37 \mathrm{ft}$ ) below grade with $\sim 2 \mathrm{~m}(7 \mathrm{ft}$ ) of fill over the top. Various ports in the tank tops are available for waste transfer and monitoring. In addition, vadose zone monitoring wells (dry wells) are located in the fill material around the tanks to allow monitoring of radionuclide migration around the tanks. The

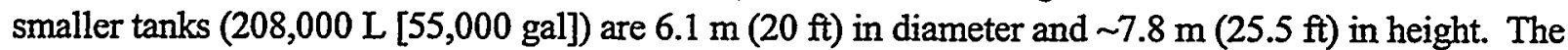
bottoms are at $\sim 11.3 \mathrm{~m}(37.25 \mathrm{ft})$ below grade and $\sim 3.6 \mathrm{~m}(11.75 \mathrm{ft})$ of fill cover the tanks. Additional details on tank construction are available in Anderson (1990).

\subsection{Operational History}

The tanks began receiving waste in 1946 (Anderson 1990) and were in more-or-less continual use from that time until 1980. The first waste sent to the U Tank Farm was metal waste resulting from the bismuth phosphate process at $B$ and $T$ Plants. Most of the metal waste was subsequently removed from the tanks and recycled through U Plant to remove uranium. The metal waste was replaced by waste from the Reduction Oxidation (REDOX) Plant and from other waste operations. Waste was transferred between tanks and tank farms throughout the operational history, and, as a result, there is considerable uncertainty about the exact composition of waste in the tanks at any particular time. Anderson (1990) provides information on tank history; historical information on the chemistry of waste disposed to the tanks is provided by Kupfer et al. (1999). Agnew (1997) provides an estimate of the composition of current tank waste based on their mixing histories.

Waste was cascaded between tanks at WMA U; however, apparently none was cascaded to cribs or ditches. There is no indication that tank waste was disposed to cribs or trenches in the vicinity of WMA U. Four of the tanks in the WMA (U-101, U-104, U-110, and U-112) have been declared leakers (Anderson 1990, DOE 1992, Hanlon 1996). There is considerable uncertainty in reported volume of the leaks; however, the two most serious leaks involved tanks U-101 and U-104. Tank U-101, declared a leaker in 1959, apparently leaked $114,000 \mathrm{~L}(-30,000 \mathrm{gal})$ of waste. Tank U-104, declared to be leaking in 1956, apparently leaked $\sim 208,000 \mathrm{~L}(55,000 \mathrm{gal})$ of waste. Tank U-110, declared to be leaking in 1975 , leaked $\sim 31,000 \mathrm{~L}(\sim 8,200)$ of waste. Tank U-112 was declared to be leaking in 1969. There is considerable uncertainty concerning the volume leaked from tank U-112, which may have been as high as $32,000 \mathrm{~L}$ (8,400 gal). All four leaking tanks have been stabilized and contain little or no pumpable liquid. 


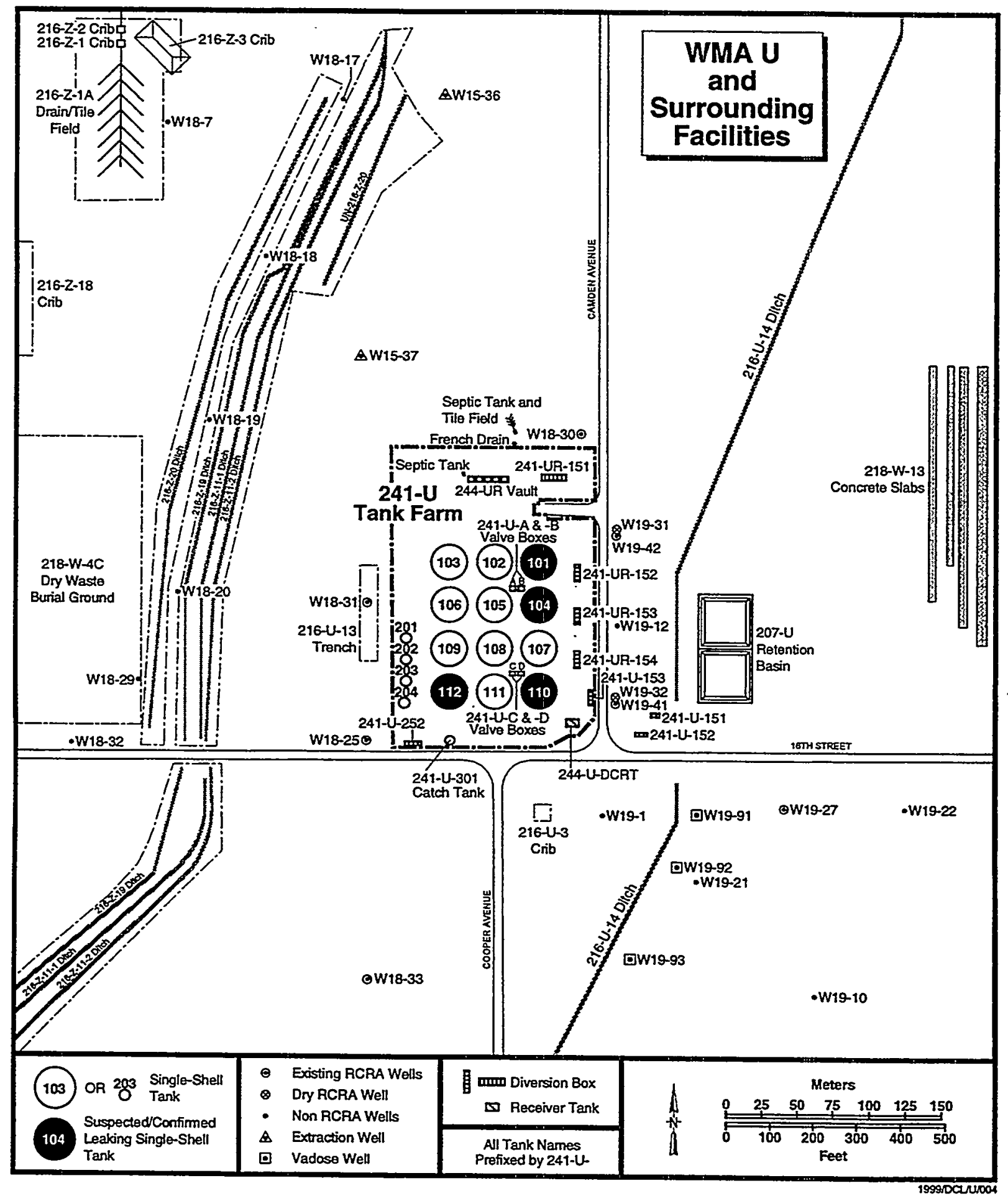

Figure 2.1. Map of Waste Management Area U, Showing Locations of Waste Tanks, Monitoring Wells, and Miscellaneous Structures. (Note: RCRA downgradient wells 299-W19-31 and 299-W19-32 are no longer sampleable and are included for historical reasons.) 
Four unplanned releases have been documented (DOE 1992). The waste volumes associated with these unplanned releases are unknown. The three releases that may have had significant impact were a beta contamination in the vicinity of the 241-U-151 and 241-U-152 diversion boxes east of WMA U ( $20 \mathrm{mr} / \mathrm{h}$ at surface), a "violent chemical reaction" at the 244-UR vault that spread first-cycle metal waste contamination over an unspecified area, and a ruptured waste line at tank U-103. DOE (1997) reported significant surface contamination within the tank farm and evidence for several unreported releases.

The 216-U-13 trench, located immediately east of the tank farm fence (see Figure 2.1), was a facility to steam clean and decontaminate vehicles and never received tank waste. The trench was stabilized by removal of contaminated soil and backfilling with clean fill (DOE 1992).

The 216-U-3 french drain is located south of WMA U, across $16^{\text {th }}$ Street. Both Waste Information Data System (WIDS) and DOE (1992) indicate that this facility received liquid from steam condensers on waste tanks in WMA U. WIDS indicates that the waste disposed at 216-U-3 contained nitrate. Kincaid et al. (1998) indicates that $216-U-3$ received $7.9 \times 10^{6} \mathrm{~L}$ of liquid; however, they list only minor amounts of fission products and actinides as contaminants.

Trenches located west of WMA U (216-Z-20, 216-Z-19, 216-Z-11-1, 216-Z-1-2) received waste from the Plutonium Finishing Plant and initially connected with the 216-U-10 Pond. Carbon tetrachloride and nitrate are the principal contaminants associated with waste from the Plutonium Finishing Plant.

\subsection{Waste Characteristics}

Waste sent to the U Tank Farm, both from the bismuth phosphate process at B and T Plants and from the REDOX process, consisted of nitric acid waste solution from the plutonium removal process that was subsequently over-neutralized with sodium hydroxide and sodium carbonate. The result was a high-pH sodium nitrate solution and contained other process chemicals, fission products, and residual actinides. Early bismuth phosphate waste contained large quantities of uranium that was subsequently removed by secondary processing at $U$ Plant. Table 2.1 presents the average total concentration of contaminants, as well as ratios of contaminants in the tanks to the drinking water standard or maximum contaminant level for selected components in the waste at WMA U. The ratio values presented in Table 2.1 give an indication of the relative magnitude of potential risk. However, other factors such as solubility, $\mathrm{K}_{\mathrm{d}}$, halflife, and biological uptake must be taken into account to determine the health risks presented by these contaminants. Values used in arriving at these unweighted averages are from Agnew (1997). The values represent bulk tank concentrations and do not distinguish between liquid and solid phases within the tanks.

As shown in Table 2.1, the tank waste is a mixed waste with a wide range of chemical and radiological constituents. In terms of chemical constituents, however, only a few are RCRA regulated and have sufficient concentration and mobility to present a potential for groundwater contamination at this time. Principal among these are chromium (hexavalent), and fluoride. Nitrite and ammonium are present in significant quantities; however, they are rarely detected in Hanford Site groundwater and are probably 
Table 2.1. Selected Waste Constituents and Average Compositions in the Tanks for Waste Management Area U (calculated from values for individual tanks in Agnew 1997)

\begin{tabular}{|c|c|c|}
\hline Waste Component & $\begin{array}{l}\text { Average Concentration } \\
\text { or Activity in the Tanks }\end{array}$ & $\begin{array}{l}\text { Concentration or Activity } \\
\text { Divided by DWS or MCL }\end{array}$ \\
\hline Sodium & $1.5 \times 10^{8} \mu \mathrm{g} / \mathrm{L}$ & (a) \\
\hline Calcium & $1.6 \times 10^{6} \mu \mathrm{g} / \mathrm{L}$ & (a) \\
\hline Chromium & $2.6 \times 10^{6} \mu \mathrm{g} / \mathrm{L}$ & 26,000 \\
\hline Nitrate & $1.4 \times 10^{8} \mu \mathrm{g} / \mathrm{L}$ & 3,111 \\
\hline Nitrite & $4.46 \times 10^{7} \mu \mathrm{g} / \mathrm{L}$ & 13,500 \\
\hline Ammonium & $6.68 \times 10^{5} \mu \mathrm{g} / \mathrm{L}$ & (a) \\
\hline Sulfate & $1.7 \times 10^{7} \mu \mathrm{g} / \mathrm{L}$ & 34 \\
\hline Chloride & $3.0 \times 10^{6} \mu \mathrm{g} / \mathrm{L}$ & (a) \\
\hline Fluoride & $6.2 \times 10^{5} \mu \mathrm{g} / \mathrm{L}$ & 155 \\
\hline Phosphate & $1.3 \times 10^{7} \mu \mathrm{g} / \mathrm{L}$ & (a) \\
\hline Carbon-14 & $2.02 \times 10^{7} \mathrm{pCi} / \mathrm{L}$ & 10,100 \\
\hline Cesium-137 & $1.59 \times 10^{11} \mathrm{pCi} / \mathrm{L}$ & $795,000,000$ \\
\hline Strontium-90 & $7.83 \times 10^{10} \mathrm{pCi} / \mathrm{L}$ & $9,790,000,000$ \\
\hline Tritium & $1.4 \times 10^{8} \mathrm{pCi} / \mathrm{L}$ & 7,000 \\
\hline Cobalt- 60 & $2.2 \times 10^{7} \mathrm{pCi} / \mathrm{L}$ & 220,000 \\
\hline Technetium-99 & $1.4 \times 10^{8} \mathrm{pCi} / \mathrm{L}$ & 155,555 \\
\hline Selenium-79 & $2.01 \times 10^{6} \mathrm{pCi} / \mathrm{L}$ & (a) \\
\hline Iodine-129 & $2.7 \times 10^{5} \mathrm{pCi} / \mathrm{L}$ & 270,000 \\
\hline Uranium-232 & $4.15 \times 10^{5} \mathrm{pCi} / \mathrm{L}$ & (a) \\
\hline Uranium-233 & $1.59 \times 10^{6} \mathrm{pCi} / \mathrm{L}$ & (a) \\
\hline Uranium-234 & $2.05 \times 10^{7} \mathrm{pCi} / \mathrm{L}$ & (a) \\
\hline Uranium-235 & $9.1 \times 10^{5} \mathrm{pCi} / \mathrm{L}$ & (a) \\
\hline Uranium-236 & $2.02 \times 10^{5} \mathrm{pCi} / \mathrm{L}$ & (a) \\
\hline Uranium-238 & $2.06 \times 10^{7} \mathrm{pCi} / \mathrm{L}$ & (a) \\
\hline Uranium & $2.52 \times 10^{5} \mu \mathrm{g} / \mathrm{L}$ & 12,600 \\
\hline Neptunium-237 & $5.19 \times 10^{5} \mathrm{pCi} / \mathrm{L}$ & 34,600 \\
\hline Plutonium-238 & $6.71 \times 10^{6} \mathrm{pCi} / \mathrm{L}$ & 44,700 \\
\hline Plutonium-239 & $3.85 \times 10^{8} \mathrm{pCi} / \mathrm{L}$ & $25,700,000$ \\
\hline Plutonium-240 & $5.52 \times 10^{7} \mathrm{pCi} / \mathrm{L}$ & $3,680,000$ \\
\hline Plutonium-241 & $3.72 \times 10^{8} \mathrm{pCi} / \mathrm{L}$ & $24,800,000$ \\
\hline Plutonium-242 & $1.6 \times 10^{3} \mathrm{pCi} / \mathrm{L}$ & 107 \\
\hline Americium-241 & $3.4 \times 10^{6} \mathrm{pCi} / \mathrm{L}$ & 227,000 \\
\hline Americium-243 & $3.92 \times 10^{3} \mathrm{pCi} / \mathrm{L}$ & 261 \\
\hline Curium-242 & $3.14 \times 10^{5} \mathrm{pCi} / \mathrm{L}$ & 20,900 \\
\hline Curium-243 & $1.33 \times 10^{4} \mathrm{pCi} / \mathrm{L}$ & 887 \\
\hline Curium-244 & $1.78 \times 10^{5} \mathrm{pCi} / \mathrm{L}$ & 11,900 \\
\hline
\end{tabular}


converted to nitrate by bacterial action within the vadose zone. Nitrate (as $\mathrm{NO}_{3}^{-}$), although it has a drinking water standard of $45,000 \mu \mathrm{g} / \mathrm{L}$, is not a RCRA regulated waste.

A number of the tanks also contain significant concentrations of organic chemicals, principally complexants used during plutonium removal. These are not listed hazardous wastes but are mobile and, therefore, elevated total organic carbon in groundwater should aid in identifying contaminants originating from the tanks. There is no evidence for significant quantities of chlorinated hydrocarbons in tank waste at WMA U; thus, total organic halides are of little or no use in indicating contamination from tank waste within the WMA.

In addition to the chemical constituents, the tank waste contains a wide variety of radioactive constituents, including cesium-137, strontium-90, cobalt-60, tritium, technetium-99, iodine-129, selenium-79, and neptunium-237, along with several isotopes of uranium and plutonium (see Table 2.1). From the perspective of transport, the most important indicators are tritium, technetium-99, and iodine-129.

\subsection{Monitoring Network}

The current groundwater monitoring network at WMA U consists of five RCRA-compliant wells and one pre-RCRA well used for information only (see Figure 2.1; Table 2.2). Two of the wells (299W18-25 and 299-W18-31) are upgradient wells. Three RCRA-compliant wells (299-W18-30, 299-W1941 , and 299-W19-42) as well as pre-RCRA well 299-W19-12 are downgradient.

Three of the original RCRA wells were constructed prior to Ecology approval of the 10.7-m (35-ft) screened intervals and were completed with $4.6-\mathrm{m}(15-\mathrm{ft})$ screened intervals. The last two of the original five RCRA wells, drilled in 1991, were completed with 10.7-m (35-ft) screened intervals. Subsequently, two of the original RCRA wells (299-W19-31 and 299-W19-32) cannot be sampled because of the decline in the water table. Two replacement wells were drilled in 1998. Well 299-W19-42 was drilled as a replacement for downgradient well 299-W19-31-and well 299-W19-41 was drilled as a replacement for downgradient well 299-W19-32. Both wells 299-W19-41 and 299-W19-42 were completed with 10.7-m (35-ft) screened intervals to extend the operational lives of the wells. Upgradient well 299-W18-25 is still sampleable but probably has less than one year of usefulness remaining. However, upgradient well 299W18-31 and downgradient well 299-W18-30 were constructed with approximately $9.1 \mathrm{~m}(30 \mathrm{ft})$ of screen below the water table and should be able to be sampled until at least 2003 .

Pre-RCRA well 299-W19-12 is sampled to fill a gap in the downgradient network and to provide continuity with pre-RCRA monitoring. Because of uncertainties about the construction, well 299-W19-12 is currently used for indication only, and indicator parameters for this well were not included in statistical analysis for WMA U. 
Table 2.2. Wells in Monitoring Network

\begin{tabular}{|c|c|c|c|c|c|}
\hline Well & $\begin{array}{l}\text { Depth to } \\
\text { Bottom of } \\
\text { Screen } \\
\text { (m) }\end{array}$ & $\begin{array}{l}\text { Depth to } \\
\text { Water } \\
\text { (m) }\end{array}$ & $\begin{array}{l}\text { Screen Length } \\
\text { (m) }\end{array}$ & $\begin{array}{l}\text { Construction } \\
\text { Casing/Screen }\end{array}$ & Monitoring Interval \\
\hline $299-W 18-25^{90}$ & 65.5 & 65.7 & 4.6 & $\mathrm{SS} / \mathrm{SS}^{(\mathrm{a})}$ & Top of unconfined \\
\hline $299-W 18-30^{91}$ & 71.4 & 68.2 & 10.7 & SS/SS & Top of unconfined \\
\hline $299-W 18-31^{91}$ & 67.8 & 65.2 & 10.7 & SS/SS & Top of unconfined \\
\hline $299-W 19-12^{83(b)}$ & 73.2 & 68.2 & 12.2 & $\mathrm{CS}^{(\mathrm{c})} / \mathrm{SS}$ & Top of unconfined \\
\hline 299-W19-31 $90(d)$ & 67.8 & - & 4.6 & SS/SS & Dry \\
\hline $299-W 19-32^{91(d)}$ & 67.8 & - & 4.6 & SS/SS & Dry \\
\hline $299-W 19-41^{98}$ & 80.6 & 68.5 & 10.7 & SS/SS & Top of unconfined \\
\hline $299-W 19-42^{98}$ & 80.8 & 68.3 & 10.7 & SS/SS & Top of unconfined \\
\hline \multicolumn{6}{|c|}{$\begin{array}{l}\text { Note: Superscript following well number denotes year of installation. } \\
\text { (a) Stainless steel. } \\
\text { (b) Pre-RCRA. } \\
\text { (c) Carbon steel. } \\
\text { (d) Unsamplable. }\end{array}$} \\
\hline
\end{tabular}




\subsection{Hydrogeology}

Stratigraphy and hydrology play a major role in subsurface contaminant movement. This chapter provides a summary of these important physical characteristics for WMA $U$ and vicinity.

\subsection{Stratigraphy}

WMA $U$ is underlain by $\sim 150 \mathrm{~m}(490 \mathrm{ft})$ of suprabasalt sediment. The major sedimentary units underlying the WMA are the Ringold Formation and the Hanford formation. The Pliocene-Pleistocene unit occurs between the Ringold Formation and the Hanford formation. A generalized stratigraphic column is presented in Figure 3.1.

The Ringold Formation consists of Miocene-Pliocene fluvial and lacustrine clastic sediment deposited by the ancestral Columbia River system. The sediment rests unconformably on the Miocene-age Columbia River Basalt Group. Lindsey (1995), using a depositional environment approach, identified a number of facies within the Ringold Formation. Using facies associations, Lindsey divided the Ringold Formation into three informal members. The Ringold Formation underlying WMA U belongs entirely to the Member of Wooded Island, the lowest member of the formation. Lindsey divided the Member of Wooded Island into five gravel-dominated fluvial depositional units, separated by widespread overbank, paleosol, and lacustrine deposits. The lower mud unit, a thick lacustrine deposit, separates gravel unit A from the overlying deposits.

The Plio-Pleistocene unit, which separates the Ringold Formation from the Hanford formation, was divided into two distinct sequences by Singleton and Lindsey (1994). The upper sequence of thinly laminated silts was identified as lacustrine deposits. Calcium carbonate-rich strata characterize the lower sequence. This lower interval consists of locally derived basaltic detritus, silt-rich eolian deposits, reworked Ringold material, and calcium carbonate-rich paleosols. The calcium carbonate occurs as thin $(<2.5-\mathrm{cm}[<1-\mathrm{ft}])$ layers, nodules, and coatings on clasts. Singleton and Lindsay also state that examination of geologic logs, split-tube samples, and cores "suggest that the well-cemented carbonate horizons may be discontinuous and highly fractured." This latter observation is important in assessing the role of the Plio-Pleistocene unit in retarding water flow through the vadose zone in this area.

The Hanford formation is an informal stratigraphic unit made up of uncemented gravel, sand, and silt deposited by the late Pleistocene Missoula glacial floods (Fecht et al. 1987, DOE 1988, Baker et al. 1991). Singleton and Lindsey (1994) described the Hanford formation in terms of three gradational facies: gravel dominated, sand dominated, and silt dominated. At both the 216-U-14 ditch (Singleton and Lindsey 1994) and at WMA U (Horton and Hodges 1999), the upper portion of the Hanford formation is gravel dominated and the lower portion is sand and silt dominated. At WMA U, the upper, graveldominated unit is $\sim 16 \mathrm{~m}(53 \mathrm{ft})$ thick, and the Hanford formation has a total thickness of $\sim 35 \mathrm{~m}$ (115 ft).

The entire suprabasalt sequence is penetrated in well 299-W19-10 (also known as DH-7), located $\sim 275 \mathrm{~m}$ (900 ft) southeast of the southeastern corner of WMA U (see Figure 2.1). In this well, the top 


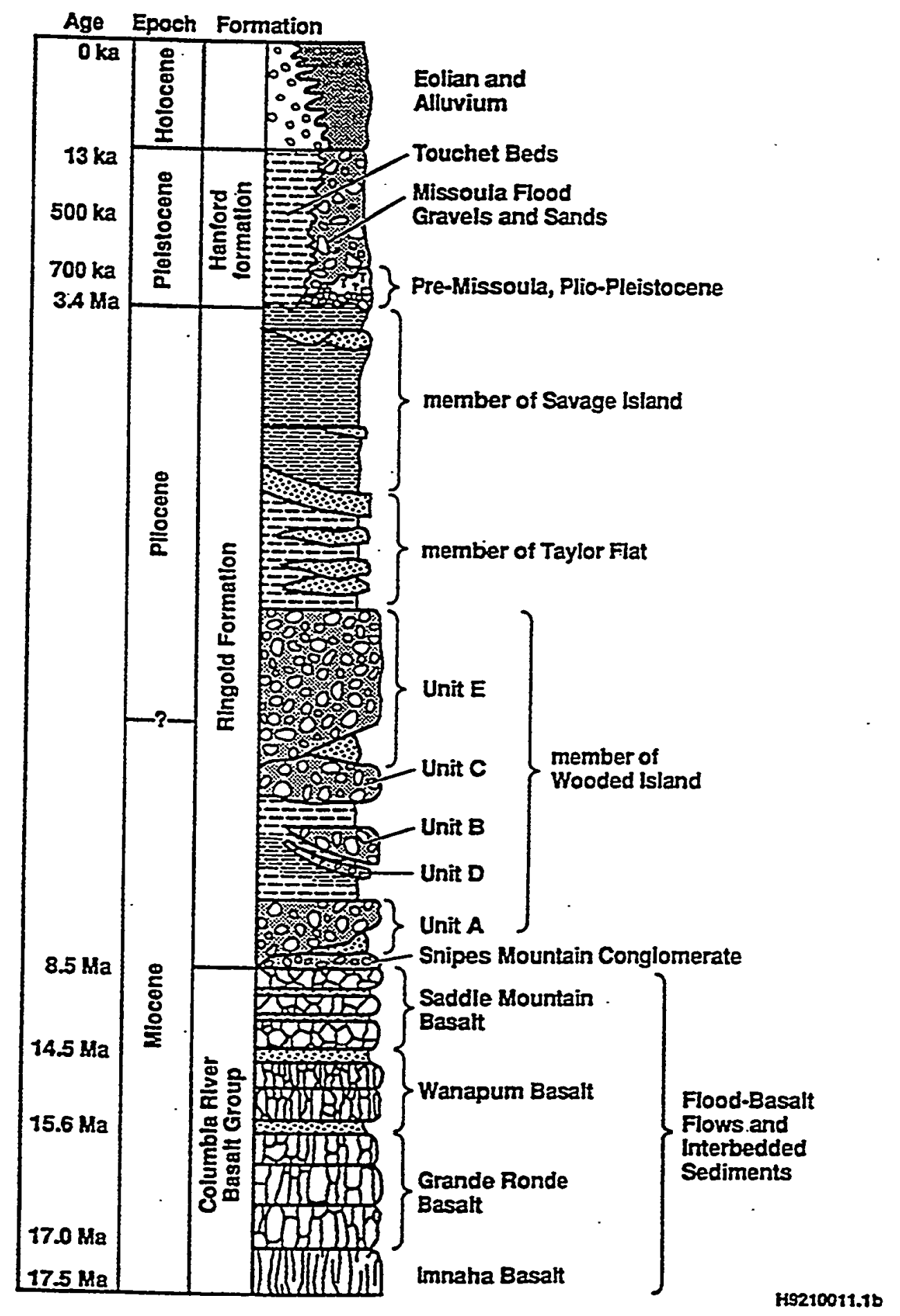

Figure 3.1. Generalized Stratigraphic Column for the Suprabasalt Sediment Beneath the 200 West Area (Lindsey 1995) 
of basalt occurs at a depth of $170 \mathrm{~m}$ (557 ft). Interpretation of core from well 299-W19-10 (Lindsay 1995 ) indicates that Ringold unit $A$, below the lower mud unit, is $\sim 23 \mathrm{~m}$ ( $75 \mathrm{ft}$ thick). The Ringold unit $\mathrm{E}$, between the lower mud and the Plio-Pleistocene unit, has a thickness of $\sim 90 \mathrm{~m}$ ( $295 \mathrm{ft})$. The upper

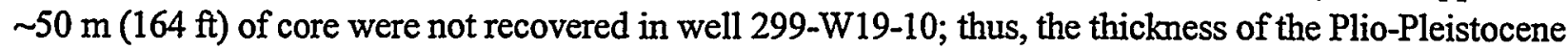
unit is not available from this well. However, geologic and geophysical logs for the two wells drilled at WMA U in 1998 (Horton and Hodges 1999) indicate a thickness of $7.3 \mathrm{~m}$ (24 ft). The thickness of the Hanford formation beneath the WMA is $\sim 35 \mathrm{~m}(116 \mathrm{ft})$.

\subsection{Physical Hydrogeology}

The water table beneath WMA U occurred at an elevation of $\sim 137 \mathrm{~m}(450 \mathrm{ft})$ in December 1998. Thus, the depth to water at that time was $69 \mathrm{~m}(226 \mathrm{ft})$, and the thickness of the saturated suprabasalt sediments was $\sim 101 \mathrm{~m}$ (331 ft). The lower mud unit is at least partly confining and is generally considered the base of the unconfined aquifer in this area. On this basis, the thickness of the unconfined aquifer is $\sim 68 \mathrm{~m}$ (223 ft). Singleton and Lindsey (1994) reported perched water beneath the 216-U-14 ditch as a result of disposal of large quantities of water to that facility; however, no evidence for perched water has been reported during drilling at WMA U.

Slug tests in RCRA monitoring wells have yielded a range of values for hydraulic conductivity from 1.1 to $11.2 \mathrm{~m} / \mathrm{d}$ (3.5 to $36.6 \mathrm{ft} / \mathrm{d}$ ). Caggiano (1994) reported hydraulic conductivity values of $1.9 \mathrm{~m} / \mathrm{d}$ $(6.1 \mathrm{ft} / \mathrm{d})$ for upgradient well $299-\mathrm{W} 18-25$ and $11.2 \mathrm{~m} / \mathrm{d}(36.6 \mathrm{ft} / \mathrm{d})$ for downgradient well 299-W19-31. Slug tests carried out in wells drilled in 1998 exhibited a similar range of values. Tests carried out in well 299-W19-41 yielded hydraulic conductivity values between 1.1 and $1.5 \mathrm{~m} / \mathrm{d}$ ( 3.5 and $5 \mathrm{ft} / \mathrm{d})$, and tests in well 299-W19-42, adjacent to well 299-W19-31, yielded hydraulic conductivity values between 7.3 and $10.7 \mathrm{~m} / \mathrm{d}$ ( 24 and $35 \mathrm{ft} / \mathrm{d})$. The variability between wells indicates differing degrees of cementation, compaction, and/or sorting within the Ringold Formation and indicates the potential for preferred flow zones within the upper portion of the unconfined aquifer. The current data indicate horizontal variability; however, data from other sites in the 200 West Area indicate that vertical variability is also present.

The rate of groundwater flow, $v$, within the unconfined aquifer beneath WMA $U$ is highly uncertain. The equation

$$
\mathrm{v}=\mathrm{Ki} / \mathrm{n}_{\mathrm{e}}
$$

where $\quad K=$ hydraulic conductivity

$\mathrm{i}=$ hydraulic gradient

$\mathrm{n}_{\mathrm{e}}=$ effective porosity

can be used to estimate the so-called "Darcy velocity;" however, this equation requires a value for effective porosity, a largely unknown parameter. Graham et al. (1981) estimated that the effective porosity for the Ringold Formation is somewhere in the range 0.1 to 0.3 , which is still the best available estimate. The hydraulic gradient in December 1998 was $\sim 0.002$. Using the measured range of hydraulic conductivities, the estimated range of effective porosities, and the December 1998 hydraulic gradient yields estimated 
groundwater flow rates ranging from 0.007 to $0.22 \mathrm{~m} / \mathrm{d}(0.02$ to $0.74 \mathrm{ft} / \mathrm{d})$. It should be noted, however, that during much of the RCRA monitoring period the hydraulic gradient was less than the current (i.e., December 1998) value.

Historically, water levels and flow directions at WMA U have been dominated by discharges to the 216-U-10 pond, located $450 \mathrm{~m}$ (1475 ft) southeast of WMA U. Effluent discharge to U Pond resulted in a 26-m (85-ft) mound on the water table (Graham et al. 1981) and a northeasterly flow direction at WMA U. U Pond was decommissioned in 1984 and, as a result, water levels dropped rapidly across a significant portion of the 200 West Area. Figure 3.2, a hydrograph for well 299-W19-1 (see Figure 2.1 for location), illustrates the effect of U Pond on water-table elevations in the vicinity of WMA U. Between June 1984

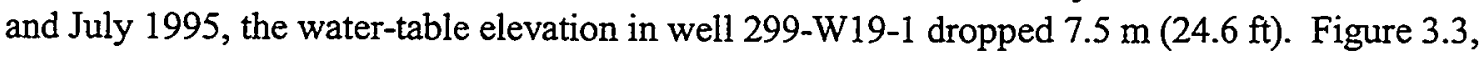
hydrographs for the RCRA monitoring wells at WMA U, shows the further decline of the water table.

A water-table map for the vicinity of WMA $U$ is presented in Figure 3.4. This water-table map, based on March 1999 data, indicates groundwater flows in an east or northeast direction. The flow directions indicated in Figure 3.4 represent the latest in a series of groundwater flow directions at the WMA that resulted from changing effluent discharge patterns in the 200 West Area through the 1980s and 1990s. These changes and their causes are discussed below.

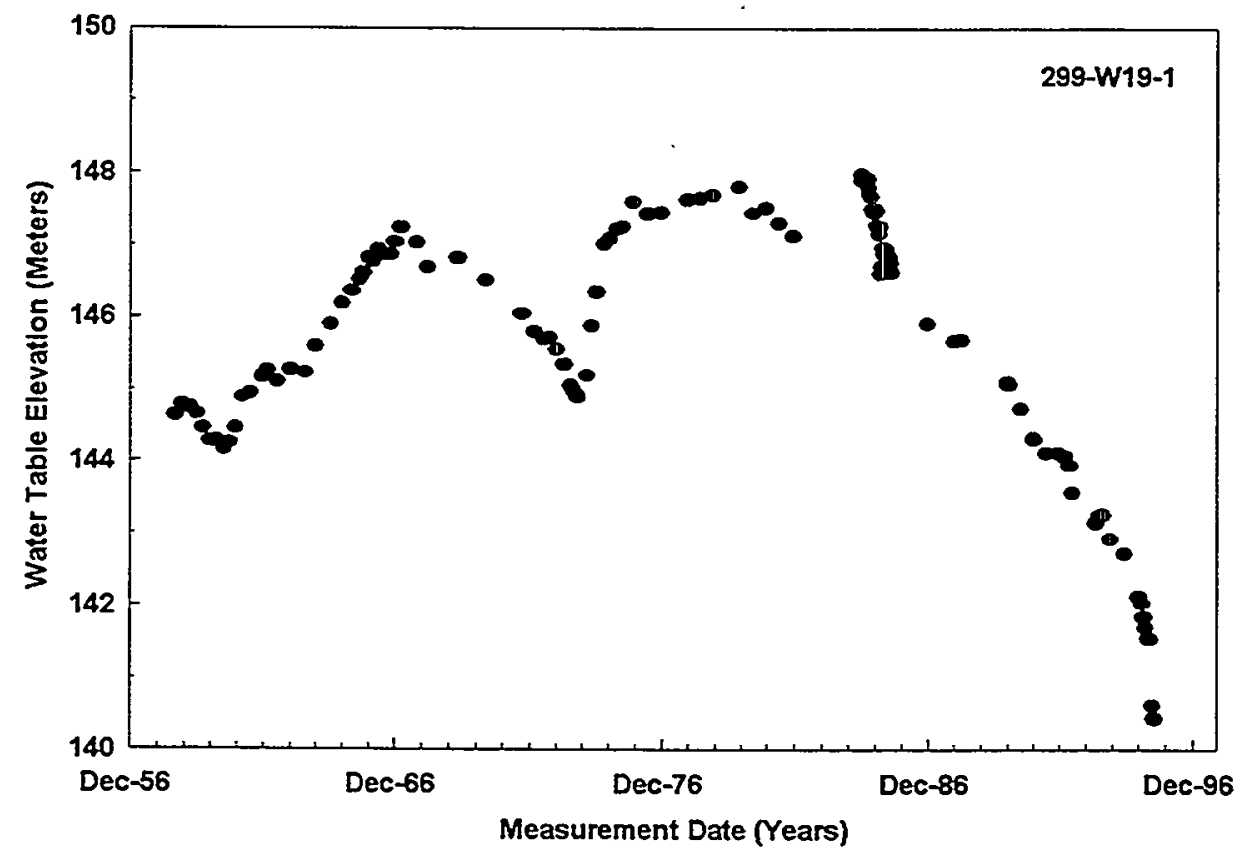

Figure 3.2. Hydrograph for Well 299-W19-1 (elevations in meters above mean sea level) 


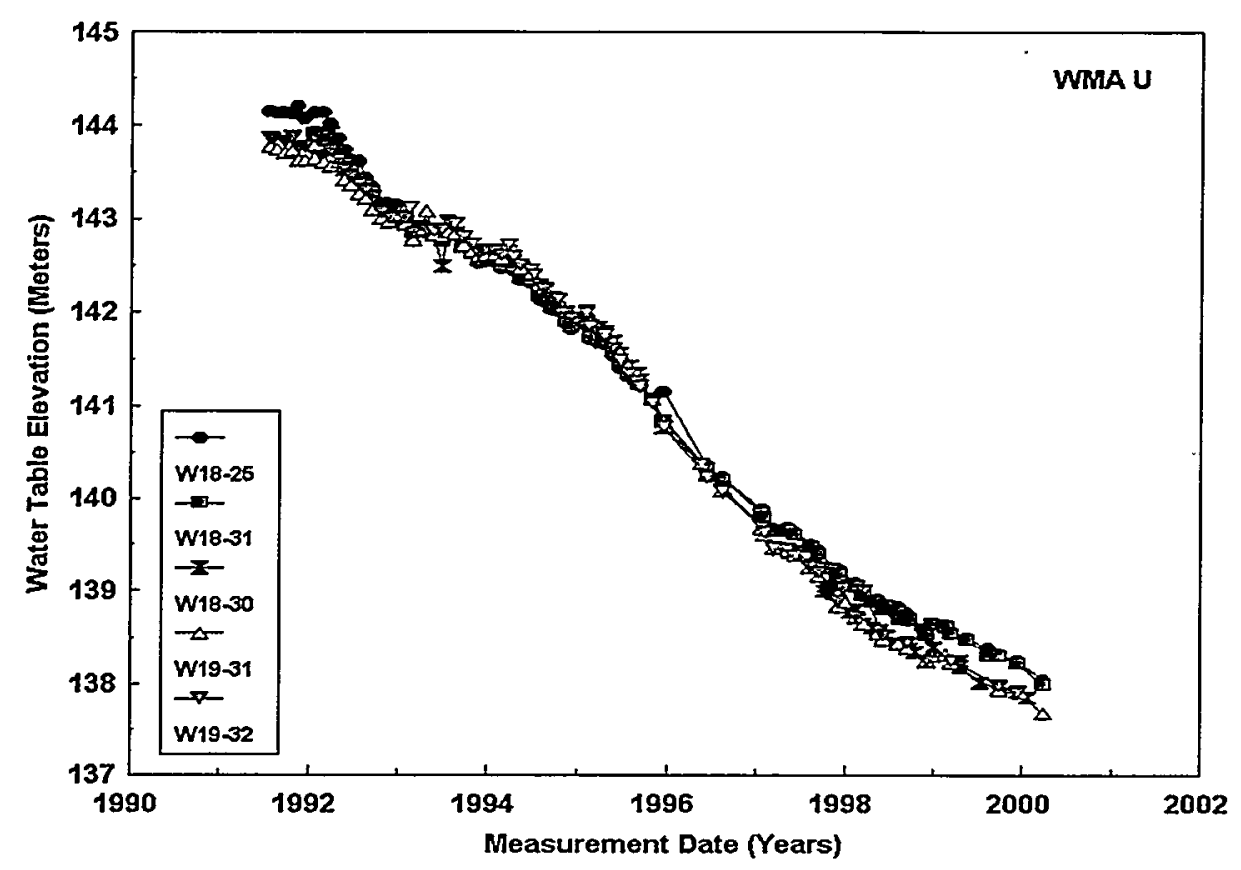

Figure 3.3. Hydrographs for RCRA Monitoring Wells at Waste Management Area U (elevations in meters above mean sea level)

After discharge of waste to U Pond ended in 1984, discharge continued at the Plutonium Finishing Plant. Because of this, the U Pond mound declined more slowly in the vicinity of the Plutonium Finishing Plant, resulting in a northward migration of the high point of the mound as the mound decreased. This northward migration of the high point of the groundwater mound resulted in a shift in the direction of groundwater flow, first to the east and then to the southeast.

During 1991 to 1993, two major effluent discharges to the 216-U-14 ditch, southeast of WMA U (Figure 3.4), resulted in a temporary reversal of flow directions at the WMA. This reversal is apparent in the hydrographs in Figure 3.3, with upgradient wells 299-W18-25 and 299-W18-31 becoming downgradient wells in early 1993 and then resuming their upgradient identities in 1996 as groundwater flow returned toward the east.

The discharges to the 216-U-14 ditch described by Singleton and Lindsey (1994) peaked in 1991 and 1993. Monitoring of vadose wells 299-W19-91, 299-W19-92, and 299-W19-93 (Figure 2.1), indicates that the discharges produced at least a $15-\mathrm{m}(50-\mathrm{ft})$ increase in the perched water table beneath the ditch. The 1991 discharge was the larger of the two, and the effects on the water table are apparent in the earliest monitoring data for the WMA. However, given the uncertainty in paths to groundwater and in travel times through the vadose zone, it is not possible to separate the effects of the two events. 


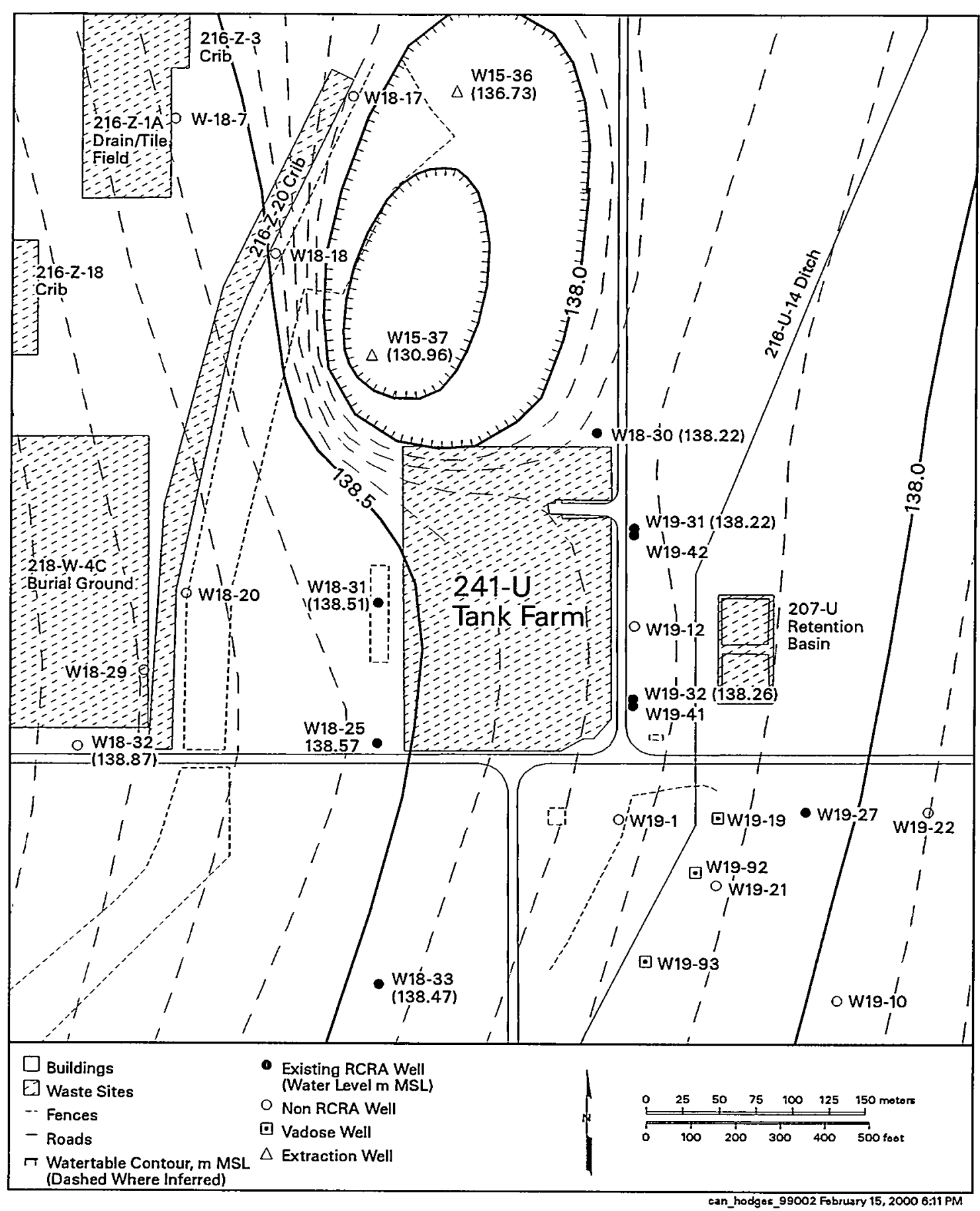

Figure 3.4. Water-Table Map (March 1999 data) for Vicinity of Waste Management Area U (elevations in meters above mean sea level) 
Phase 3 of the 200-ZP-1 Operable Unit pump-and-treat operation started in August 1997 (DOE 2000). This pump-and-treat operation was designed to stabilize the carbon tetrachloride plume from past disposal to cribs near the Plutonium Finishing Plant. The operation extracts contaminated groundwater from a series of wells east of the Plutonium Finishing Plant, between WMAs U and TX-TY to the north. Well 299-W15-37, located $100 \mathrm{~m}$ (330 ft) northwest of the WMA (see Figure 3.4), is the nearest extraction well to the pump-and-treat operation. After removal of carbon tetrachloride, the water is reinjected into the aquifer in several wells immediately west of the 200 West Area boundary.

As a result of the pump-and-treat activities, groundwater flows slightly north of east in the southern part of WMA $U$ and flows toward the north or slightly west of north in the northern portion of the WMA U. This condition may represent relative stability, as long as the pump-and-treat operations do not change. However, there is also a chance that changing flow directions, and potential injection of contaminants upgradient to the WMA, may result in changes in upgradient contaminant chemistry. 


\subsection{Summary of Groundwater Monitoring Results}

Historical, pre-RCRA, as well as more recent RCRA groundwater monitoring results were used to evaluate contaminant distribution patterns, dynamics and possible source areas in the vicinity of WMA U. Results of this data review and evaluation are described in the following sections and, together with information from Chapter 3, form the basis for the conceptual model presented in Chapter 5.

\subsection{Pre-RCRA Monitoring}

Although operations started at WMA $U$ in 1944, there is no indication of groundwater monitoring prior to the completion of downgradient well 299-W19-12 in January 1983. Starting in May 1983 groundwater from well 299-W19-12 was analyzed for a number of radionuclides (cesium-137, cobalt-60, ruthenium-106, strontium-90, tritium, and uranium), gross alpha, gross beta and nitrate. Technetium-99 was added to the list in 1988.

Nitrate concentration in well $299-\mathrm{W} 19-12$ was $40,700 \mu \mathrm{g} / \mathrm{L}$ when monitoring was initiated in May 1983 (Figure 4.1). Nitrate dropped rapidly after initiation of monitoring, reaching a low of $2,530 \mu \mathrm{g} / \mathrm{L}$ in March of 1984 before rebounding to $16,700 \mu \mathrm{g} / \mathrm{L}$ in April of 1990 .

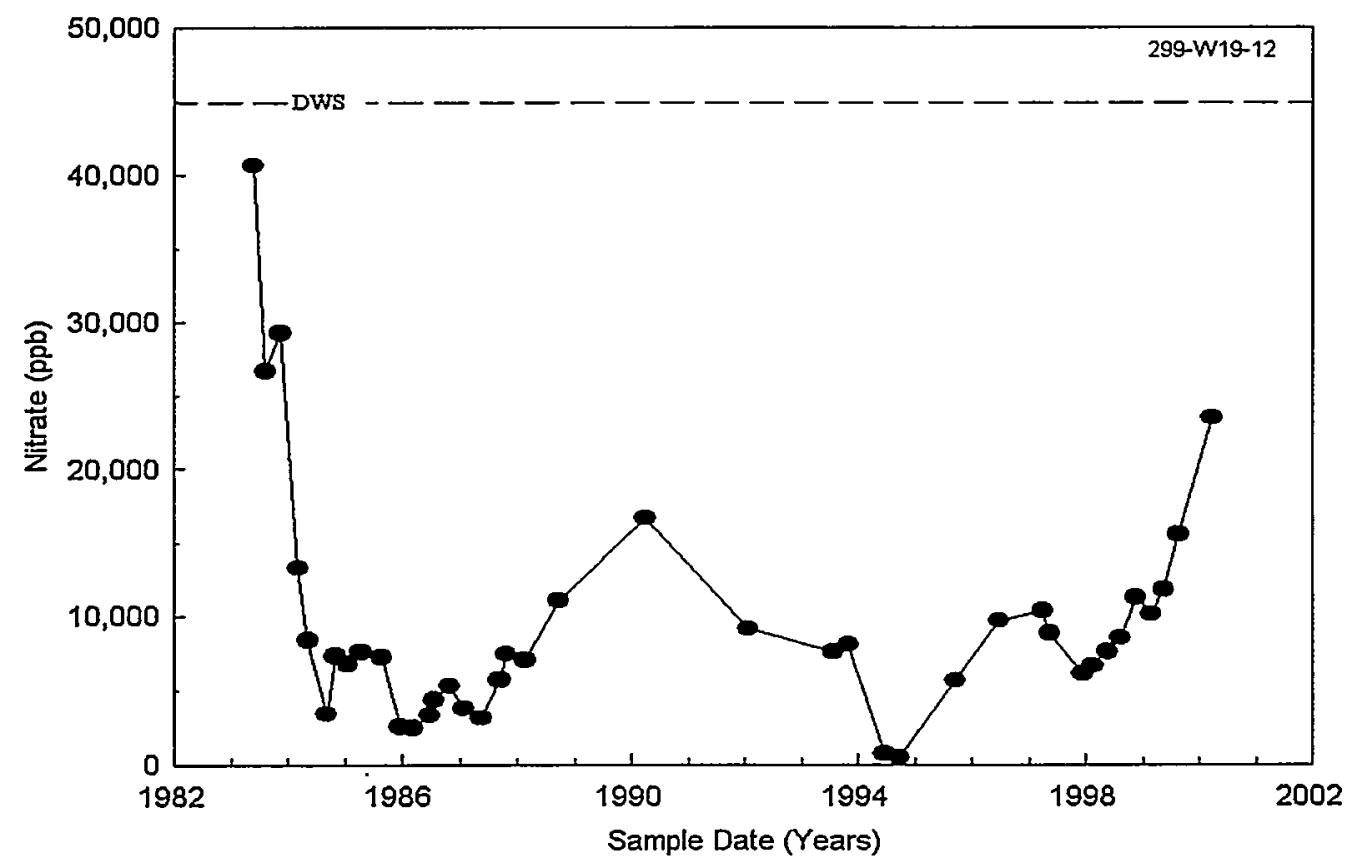

Figure 4.1. Nitrate Concentrations $(\mu \mathrm{g} / \mathrm{L})$ in Pre-RCRA Monitoring Well 299-W19-12

Small increases in tritium, gross alpha, and gross beta in late 1983 to early 1985 may have indicated the passing of a contaminant plume at that time. It is impossible to determine whether this plume was 
related to WMA $U$ because of the lack of upgradient monitoring at that time. Tritium, which had been below detection, reached a maximum of $1,480 \mathrm{pCi} / \mathrm{L}$, gross alpha increased to $11.6 \mathrm{pCi} / \mathrm{L}$, and gross beta increased to $60 \mathrm{pCi} / \mathrm{L}$. There was normally a high correspondence between values of uranium and gross alpha in well 299-W19-12; however, two high gross alpha samples in 1984 were not accompanied by increased uranium, indicating the possibility that some other alpha emitting radionuclide was present in the groundwater at that time.

Shortly after the initiation of monitoring for technetium-99, concentrations for this radionuclide rose to $2,350 \mathrm{pCi} / \mathrm{L}$ in September 1988 (Figure 4.2). Technetium-99 was not analyzed again until June 1992 and at that time concentrations had dropped to $302 \mathrm{pCi} / \mathrm{L}$. Gross beta values of $337 \mathrm{pCi} / \mathrm{L}$ in September 1988 and $339 \mathrm{pCi} / \mathrm{L}$ in April 1990 indicate that the pulse of technetium might have lasted for some time and could have reached activities considerably greater that the one measured value.

Pre-RCRA monitoring indicates that contaminant plumes were present beneath the WMA. However, the absence of upgradient wells makes it impossible to determine whether the WMA was the source.

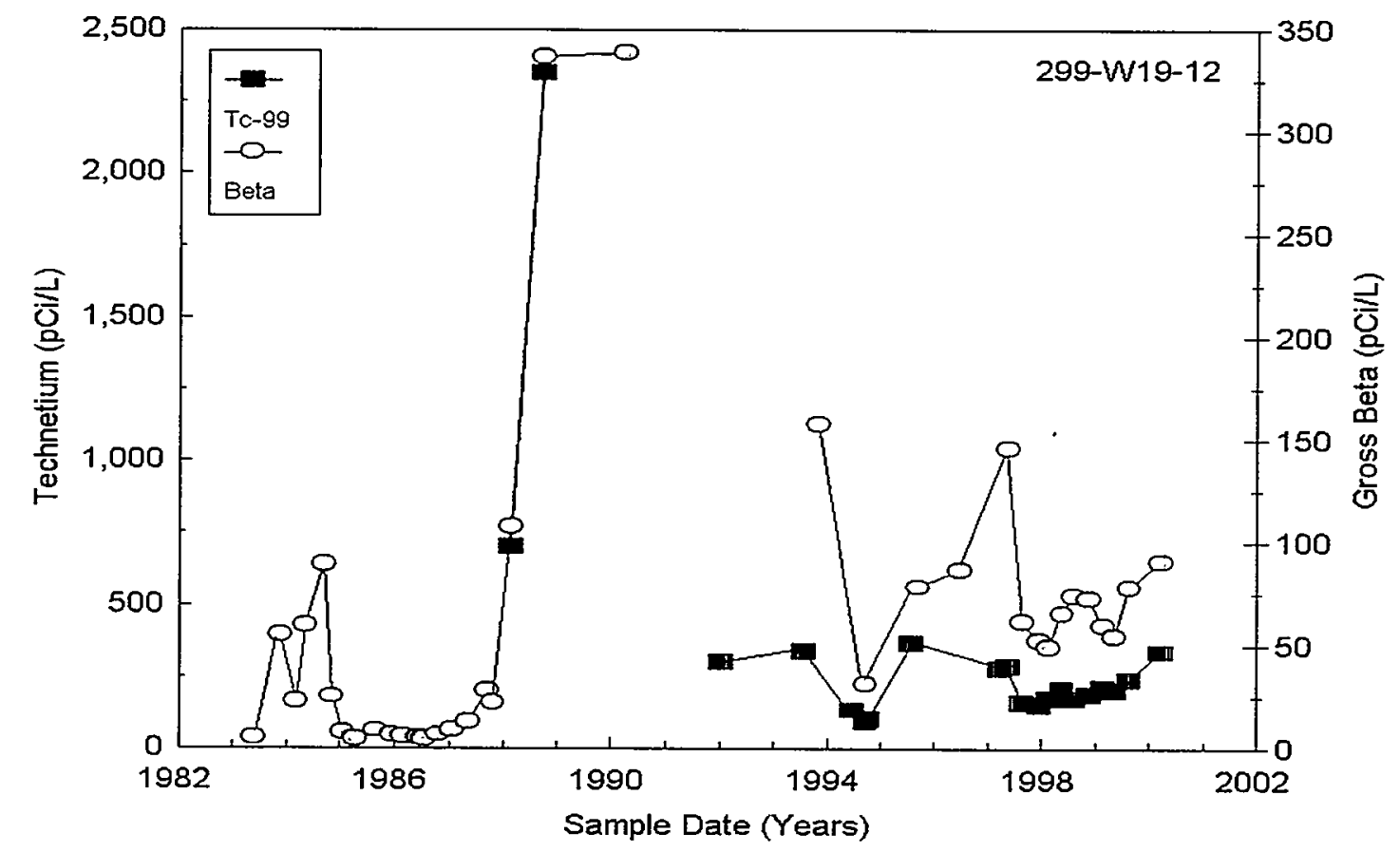

Figure 4.2. Technetium-99 and Gross Beta Concentrations (pCi/L) in Pre-RCRA Monitoring Well 299-W19-12

\subsection{RCRA Monitoring}

RCRA monitoring in two upgradient and three downgradient wells was initiated between April 1991 and April 1992. The initial four quarters of sampling to determine upgradient-downgradient comparison 
values for the RCRA indicator parameters was completed in March of 1993. The upgradientdowngradient comparison values have been re-established several times since that date in order to reflect changing groundwater flow directions at the WMA.

The most recent recalculation of critical means, in August 1999, resulted in an exceedance for specific conductance in downgradient well 299-W19-41. The new critical mean of $273 \mu \mathrm{S} / \mathrm{cm}$ is considerably lower than the previous value of $533 \mu \mathrm{S} / \mathrm{cm}$, as a result of decreased variability in upgradient wells (Hodges and Chou 2000; Figure 4.3). The exceedance is a result of a lower critical mean, not an increase in specific conductance in well 299-W19-41.

During the period of RCRA monitoring there have been no exceedances in RCRA monitoring wells for RCRA indicator parameter $\mathrm{pH}$. Values for total organic carbon exceeded the critical mean in several wells in February 1997; however, this was apparently a result of analytical bias that affected wells across the Hanford Site (Chou 1998). There have been numerous exceedances for total organic halides as discussed below. Other groundwater constituents that have shown significant variation at WMA U include calcium, chloride, nitrate, sodium, sulfate, and technetium-99. In discussing variations in groundwater chemistry it is useful to consider two groups of wells that have exhibited similar chemical behavior. The first group consists of upgradient wells 299-W18-25 and 299-W18-31 and downgradient well 299-W18-30. Well 299-W18-30 apparently has been largely unaffected by WMA U and groundwater in that well is chemically similar to that of the upgradient wells. The second group is made

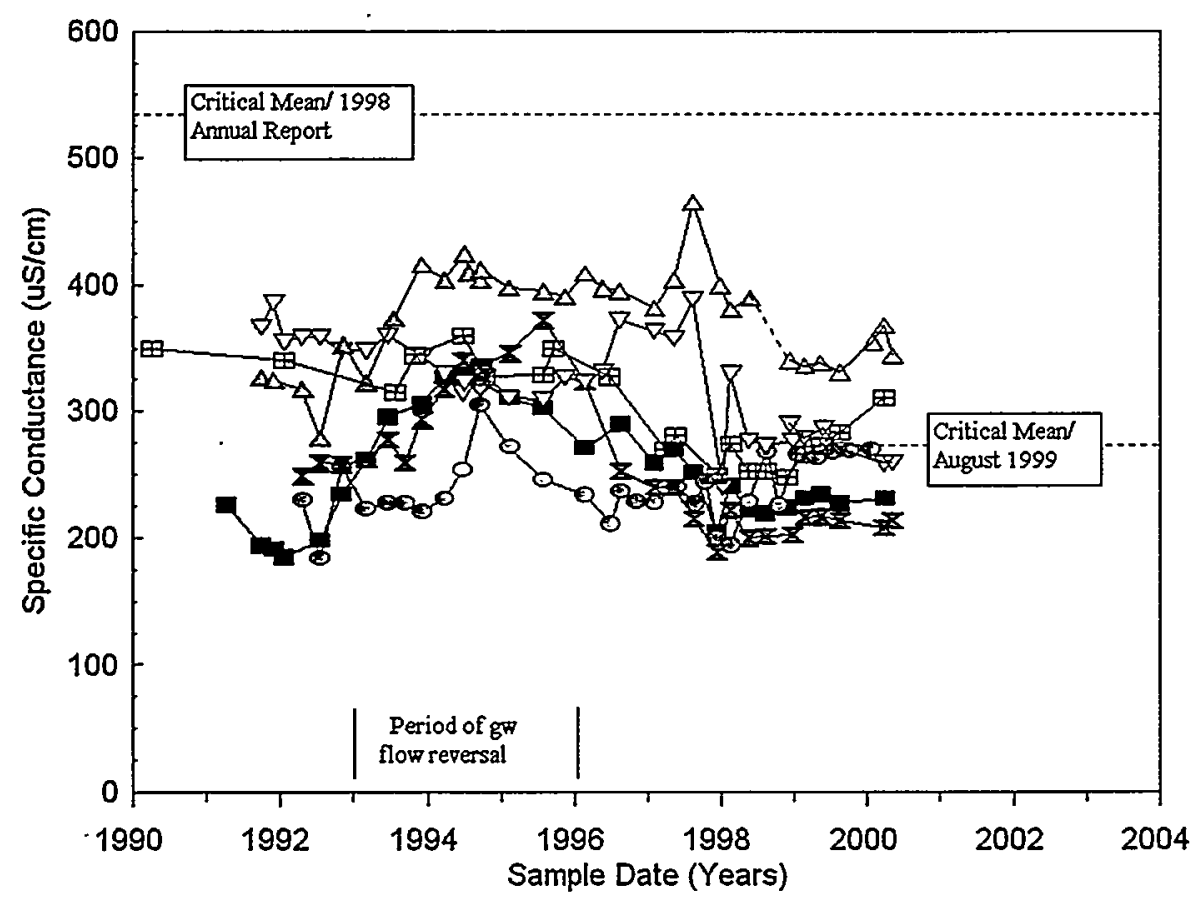

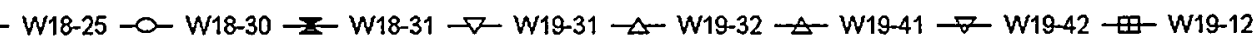

Figure 4.3. Specific Conductance Values for Wells in the WMA U Monitoring Network 
up of downgradient wells 299-W19-12, 299-W19-31, 299-W19-32, 299-W19-41, and 299-W19-42. These downgradient wells are similar in their chemical patterns and groundwater sampled by these wells has apparently been affected by WMA U.

\subsubsection{Specific Conductance}

The critical mean for specific conductance at WMA U has historically been relatively high because of the high degree of variability in measurements in upgradient wells (Hodges and Chou 2000; Figure 4.3). This variability is largely a result of highly variable groundwater flow directions at the WMA and higher specific conductivity values during the period of groundwater flow reversal (Figure 4.3). As a result of changes in the direction of groundwater flow the critical means for WMA U have been recalculated several times since the initiation of RCRA monitoring. The most recent recalculation of the critical mean for specific conductance, using data collected from August 1998 to August 1999, resulted in a significant lowering ( $50 \%)$ of the critical mean value. Specific conductance values for downgradient well 299W19-41, located at the southeast corner of WMA U exceed the new critical mean.

Historically, specific conductance values in wells at the southeast corner of the WMA, well 299W19-32 and its replacement 299-W19-41, have been higher than values reported for other wells in the monitoring network (Figure 4.3). The higher specific conductance in these wells is principally a result of higher alkalinity (bicarbonate), calcium, chloride, magnesium, sodium, and sulfate, Nitrate is increasing in well 299-W19-41; however, it does not make a significant contribution to specific conductance in this well.

The clearest link between specific conductance and groundwater chemistry is through the equivalents of dissolved ionic solids present in the groundwater. The major element chemistries of recent groundwater samples from WMA $U$, in terms of milliequivalents, are presented in Table 4.1. All major components, with the exception of potassium, are higher in well 299-W19-41 than in the upgradient wells; however, the major contributors to the higher specific conductance are naturally occurring constituents: chloride, sulfate, calcium, magnesium, and alkalinity (bicarbonate).

\subsubsection{Total Organic Halides}

There have been a number of exceedances of the critical mean for total organic halides during the RCRA monitoring period. Halogenated hydrocarbons are not significant constituents of Hanford tank waste and the elevated values for total organic halides detected in the RCRA monitoring network at WMA U are the result of a carbon tetrachloride plume originating at the Plutonium Finishing Plant. Maps for this plume are presented in DOE (2000) and Hartman et al. (2000). The plume, which is encroaching on WMA $U$ from the west and northwest, was distorted in the vicinity of WMA $U$ by the reversal in flow direction produced by the discharges to the $216-\mathrm{U}-14$ ditch in the early 1990 s. Currently the concentration of total organic halides in wells at WMA $U$ are increasing, probably as a result of the 200-ZP-1 Pump-and-Treat Operations (DOE 2000). Measured carbon tetrachloride concentrations at WMA U have exceeded the EPA Maximum Contaminant Level (MCL) of $5 \mu \mathrm{g} / \mathrm{L}$ in both upgradient and downgradient wells throughout the period of RCRA monitoring. The highest reported carbon tetrachloride concentration was $994 \mu \mathrm{g} / \mathrm{L}$ in well 299-W18-30 in July 1996. 
Table 4.1. Milliequivalents in Recent Waste Management Area U Groundwater Samples

\begin{tabular}{|c|c|c|c|c|c|c|c|}
\hline Well & 299-W19-41 & 299-W19-41 & 299-W19-32 & 299-W19-42 & 299-W18-30 & 299-W18-25 & 299-W18-31 \\
\hline Date & $8 / 17 / 99$ & $1 / 26 / 00$ & $5 / 28 / 98^{(a)}$ & $8 / 17 / 99$ & $10 / 7 / 99$ & $8 / 18 / 99$ & $8 / 17 / 99$ \\
\hline \multicolumn{8}{|c|}{ Cations (meq) } \\
\hline Sodium & $0.88(24.9 \%)^{(b)}$ & $0.83(24.5 \%)$ & $0.91(22.8 \%)$ & $0.81(27.5 \%)$ & $0.80(30.1 \%)$ & $0.66(27.0 \%)$ & $0.60(26.1 \%)$ \\
\hline Potassium & $0.12(3.3 \%)$ & $0.10(2.9 \%)$ & $0.13(3.3 \%)$ & $0.08(2.7 \%)$ & $0.10(3.8 \%)$ & $0.07(2.9 \%)$ & $0.11(4.8 \%)$ \\
\hline Calcium & $1.64(46.5 \%)$ & $1.59(47.1 \%)$ & $2.00(50.0 \%)$ & $1.33(45.1 \%)$ & $1.16(62.4 \%)$ & $1.09(44.7 \%)$ & $1.03(44.8 \%)$ \\
\hline Magnesium & $0.89(25.2 \%)$ & $0.86(25.5 \%)$ & $0.96(24.0 \%)$ & $0.73(24.7 \%)$ & $0.60(25.4 \%)$ & $0.62(25.4 \%)$ & $0.56(24.3 \%)$ \\
\hline Sum & 3.53 & 3.37 & 4.00 & 2.95 & 2.66 & 2.44 & 2.30 \\
\hline \multicolumn{8}{|c|}{ Anions (meq) } \\
\hline Chloride & $0.40(12.3 \%)$ & $0.45(12.3 \%)$ & $0.83(22.0 \%)$ & $0.20(7.5 \%)$ & $0.17(6.3 \%)$ & $0.16(6.6 \%)$ & $0.11(5.0 \%)$ \\
\hline Sulfate & $0.59(18.1 \%)$ & $0.71(19.5 \%)$ & $0.71(18.8 \%)$ & $0.44(16.4 \%)$ & $0.43(15.8 \%)$ & $0.40(16.5 \%)$ & $0.33(15.1 \%)$ \\
\hline Alkalinity & $2.04(62.6 \%)$ & $2.18(60.0 \%)$ & $2.20(58.4 \%)$ & $1.80(67.2 \%)$ & $1.92(70.6 \%)$ & $1.76(78.7 \%)$ & $1.70(77.6 \%)$ \\
\hline Nitrate & $0.23(7.0 \%)$ & $0.30(8.2 \%)$ & $0.03(0.8 \%)$ & $0.24(9.0 \%)$ & $0.20(7.4 \%)$ & $0.10(4.1 \%)$ & $0.05(2.3 \%)$ \\
\hline Sum & 3.26 & 3.63 & 3.77 & 2.68 & 2.72 & 2.42 & 2.19 \\
\hline $\begin{array}{l}\text { Specific } \\
\text { Conductance }\end{array}$ & $331 \mu \mathrm{S} / \mathrm{cm}$ & $\begin{array}{l}355 \mu \mathrm{S} / \mathrm{cm}^{(\mathrm{c})} \\
343 \mu \mathrm{S} / \mathrm{cm}^{(\mathrm{d})}\end{array}$ & $390 \mu \mathrm{S} / \mathrm{cm}$ & $270 \mu \mathrm{S} / \mathrm{cm}$ & $269 \mu \mathrm{S} / \mathrm{cm}$ & $227 \mu \mathrm{S} / \mathrm{cm}$ & $214 \mu \mathrm{S} / \mathrm{cm}$ \\
\hline \multicolumn{8}{|c|}{$\begin{array}{l}\text { (a) Last available sample from well. } \\
\text { (b) Percentage of total cations or anions. } \\
\text { (c) Field measurement. } \\
\text { (d) Laboratory measurement. }\end{array}$} \\
\hline
\end{tabular}




\subsubsection{Nitrate}

Nitrate shows the widest variation during the RCRA monitoring period. Nitrate variation for wells 299-W18-25, 299-W18-30, and 299-W18-31 is shown in Figure 4.4a and for wells 299-W19-12, 299W19-31, 299-W19-32, 299-W19-41 and 299-W19-42 in Figure 4.4b.

Nitrate peaked near 20,000 $\mu \mathrm{g} / \mathrm{L}$ in downgradient well 299-W19-31 in 1992 and in downgradient well 299-W19-32 in 1993, prior to falling below $1,000 \mu \mathrm{g} / \mathrm{L}$ in 1994, during the groundwater flow reversal. After 1994 nitrate values increased, particularly in well 299-W19-31, reaching a peak value of 42,000 $\mu \mathrm{g} / \mathrm{L}$ in early 1997, after which it declined until regular sampling from this well stopped in late 1998.

Nitrate concentrations remained relatively low in well 299-W19-32 following the nitrate minimum in 1994; the last sample taken in May $1998 \mathrm{had}$ a nitrate concentration of $1,680 \mu \mathrm{g} / \mathrm{L}$. There was no overlap between the sampling of well 299-W19-32 and replacement well 299-W19-41. When sampling started in well 299-W19-41, in December 1998, the nitrate concentration was $5,800 \mu \mathrm{g} / \mathrm{L}$ and has exhibited an increasing trend since that time. The most recent data, from samples collected in March 2000 , had a nitrate concentration of $19,500 \mu \mathrm{g} / \mathrm{L}$. Nitrate concentrations in non-RCRA well 299-W19-12, located between wells 299-W19-41 and 299-W19-42, have followed a pattern somewhat similar to that in wells 299-W19-32 and 299-W19-41; however, nitrate concentrations started to increase sharply prior to the increase in the southern well pair.

Nitrate in upgradient wells 299-W18-25 and 299-W18-31, and downgradient well 299-W18-30 started to increase in a south to north sequence between late 1993 and early 1994 . Nitrate in these wells peaked in 1995 and subsequently declined until early 1997 at which time concentrations started to increase, particularly in well 299-W18-30. The highest nitrate concentrations observed in upgradient wells 299-W18-25 and 299-W18-31 was during the period of groundwater flow reversal, when these well would have been sampling water moving from beneath WMA U.

In December 1998, samples from well 299-W19-31 and replacement well 299-W19-42, drilled immediately adjacent to well 299-W19-31, indicate that the nitrate concentration in well 299-W19-42 is significantly higher than that in well 299-W19-31. Because the only essential difference between the two samples is pump depth, this suggests an increase in nitrate concentration with increasing depth. Subsequent nitrate concentrations in well 299-W19-42 decreased along a trend roughly parallel to that set by concentrations in well 299-W19-31. Interestingly, well 299-W19-31 was sampled by mistake in December 1999. The sample was turbid (60 NTU); however, the decreasing trend of nitrate concentration observed up to December 1998 continued, parallel to but lower than the trend for well 299-W19-42.

There are upgradient sources of nitrate, principally the cribs and trenches associated with the Plutonium Finishing Plant; however, these sources do not account for all of the nitrate detected in downgradient wells at WMA U. The nitrate concentration patterns observed at WMA U between 1992 and 1997 are consistent with a nitrate source beneath the WMA. The decrease in nitrate concentrations in downgradient wells and the sequential increase, from south to north, in the upgradient wells is consistent with a nitrate source beneath the southern portion of the WMA that was pushed to the north and west by 

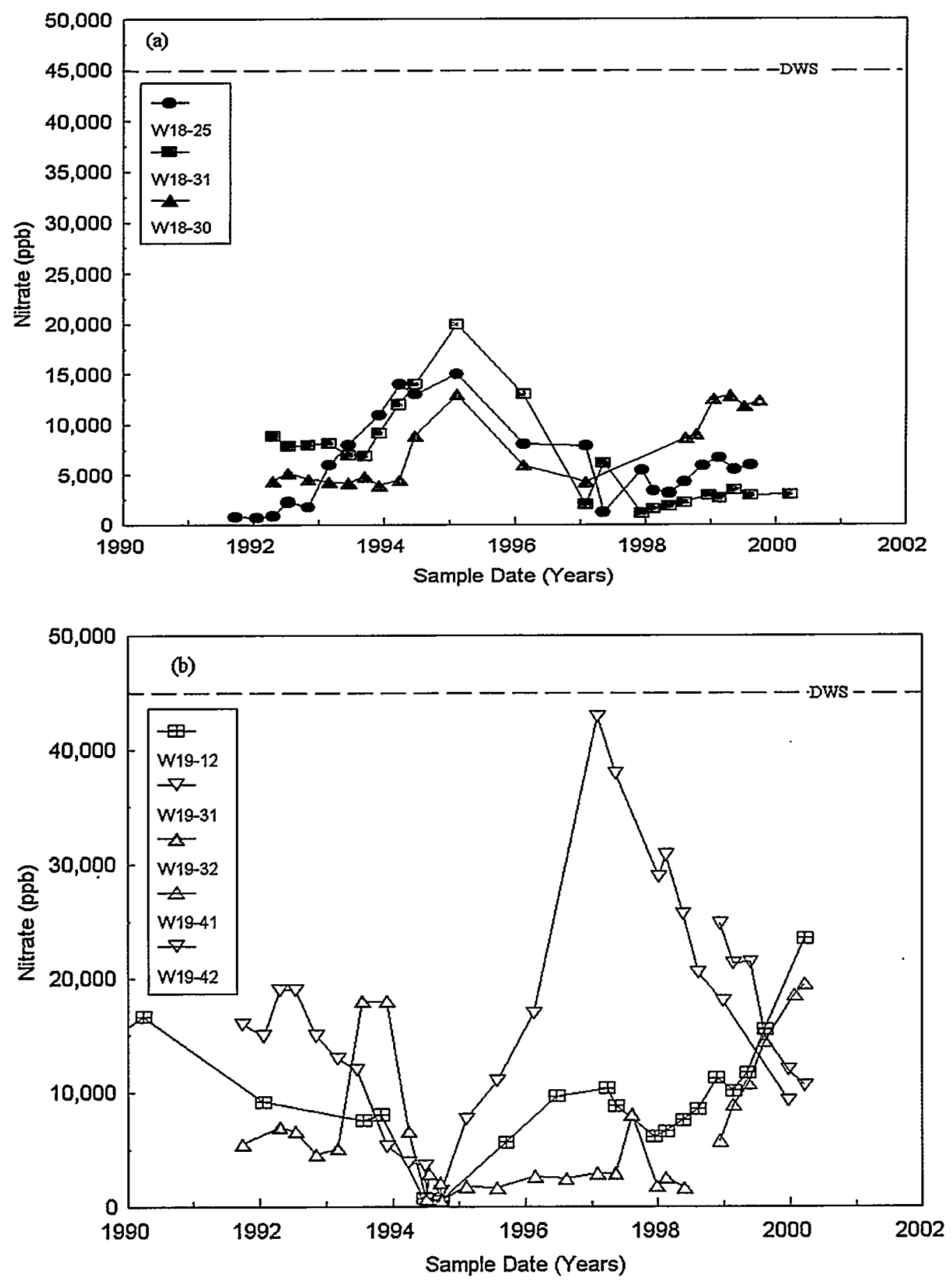

Figure 4.4. Plot of Nitrate Concentrations $(\mu \mathrm{g} / \mathrm{L})$ in Monitoring Wells at WMA U. (a) Concentrations in wells 299-W18-25, 299-W18-31, and 299-W18-30. (b) Concentrations in 299-W19-12, 299-W19-31, 29-W19-32, 299-W19-41, and 299-W19-42. 
the influx of water at the 216-U-14 ditch. The subsequent rise and fall of nitrate concentrations in well 299-W19-31, and its replacement well 299-W19-42, and the sequential increase in nitrate concentrations in wells 299-W19-12 and 299-W19-41 are also consistent with a source in the southern part of WMA U affecting wells in a north to south sequence as groundwater flow swung around to a more easterly orientation after the reversal in flow direction between 1993 and 1996. The post 1997 increase in well 299-W18-30 is probably a result of the northerly flow direction induced by the pump-and-treat activity north of the WMA. The mixing of nitrate from a source at WMA $U$ with nitrate from an upgradient source is discussed in Chapter 5 (see Figure 5.2).

\subsubsection{Technetium-99}

Technetium-99 has been present in significant quantities in groundwater sampled by downgradient wells 299-W19-12, 299-W19-31, and 299-W19-32 throughout the RCRA monitoring period, and more recently in wells 299-W19-41 and 299-W19-42. However, with the exception of one sample from well 299-W19-32, concentrations have remained below the DWS (900 pCi/L) (Figure 4.5). Prior to the reversal in the direction of groundwater flow in 1993, groundwater flow was toward the southeast. Thus, the 1993 technetium-99 peak in well 299-W19-32, located at the southeast corner of WMA U, could simply be the result of a technetium-99 plume moving southeast that was swept back under the WMA by the change in the direction of groundwater flow. An alternative source for the technetium-99 peak observed in well 299-W19-32 is effluents discharged to the 216-U-14 ditch; however, Singleton and Lindsey (1994) report that technetium-99 was below detection in perched water beneath the ditch. Technetium-99 concentrations in downgradient wells reached minimum values in 1994. This was during the period of groundwater flow reversal, coincident with the minimum in nitrate concentrations in downgradient wells (Figure 4.4b), and technetium-99 levels have generally increased since that time. In 1996, technetium-99 concentrations peaked in well 299-W19-31, coincident with the peak in nitrate concentration in that well.

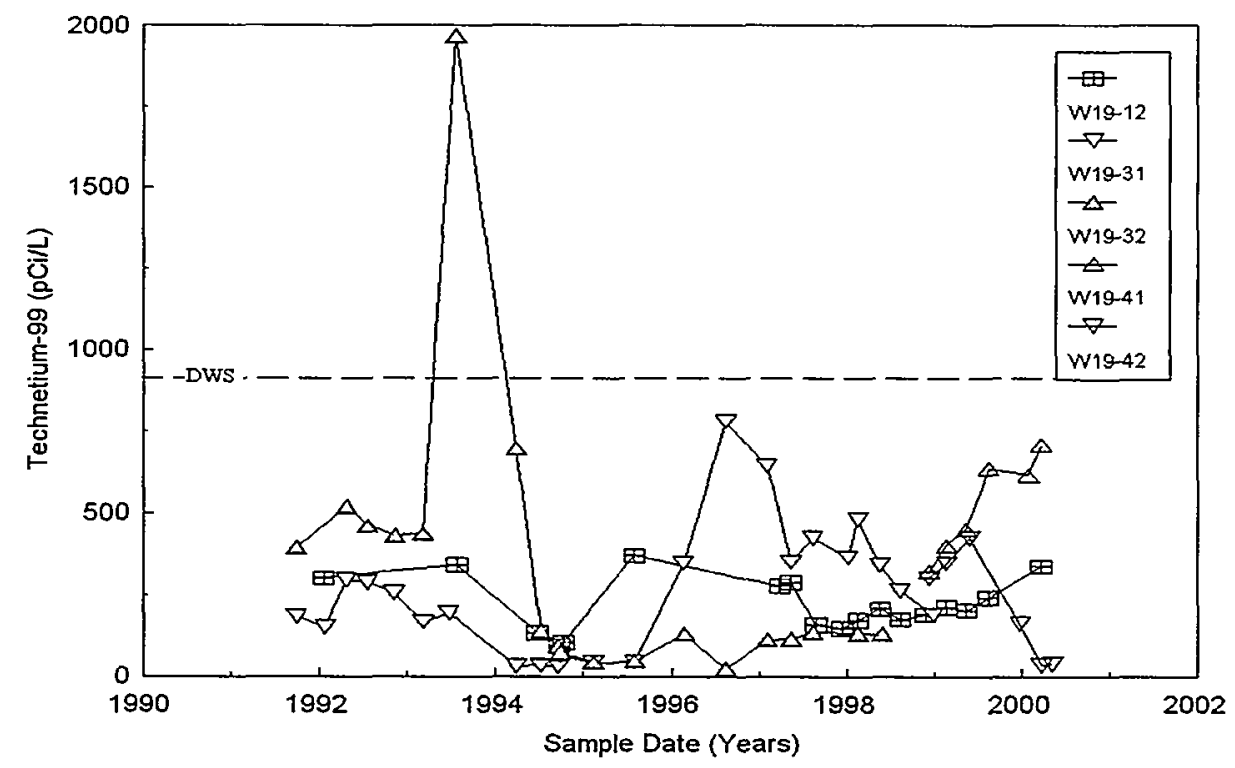

Figure 4.5. Plot of Technetium-99 Concentrations (unfiltered) for Downgradient Wells at WMA U 
Technetium-99 has increased in replacement well 299-W19-41, along with nitrate, since the start of sampling in December 1998. After an initial increase, technetium-99 levels in replacement well 299W19-42 have dropped sharply. The higher technetium-99 concentrations in well 299-W19-41 for the December 1998 sampling is consistent with the observed increase in nitrate concentrations with depth observed for the well pair for the same sampling. The reason for the initial increase in technetium-99 concentrations in 299-W19-42 is unknown; however, the subsequent decline is consistent with the trend of technetium-99 in well 299-W19-31 and with the declining trend of nitrate concentrations in both wells.

During the RCRA sampling period technetium-99 has been below detection, or, when detected, less than $10 \mathrm{pCi} / \mathrm{L}$, in wells $299-\mathrm{W} 18-25,299-\mathrm{W} 18-30$, and 299-W18-31. Figure 4.6 is a plot of all technetium-99 data (detects and nondetects) from both upgradient and downgradient wells. This plot clearly shows the difference between the two sets of wells and indicates the lack of an upgradient source for technetium-99 at WMA U. The lack of an upgradient source for technetium-99, coupled with the observed variation pattern in the downgradient well, which is very similar to that observed for nitrate, is consistent with a technetium-99 source beneath the southern portion of WMA U.

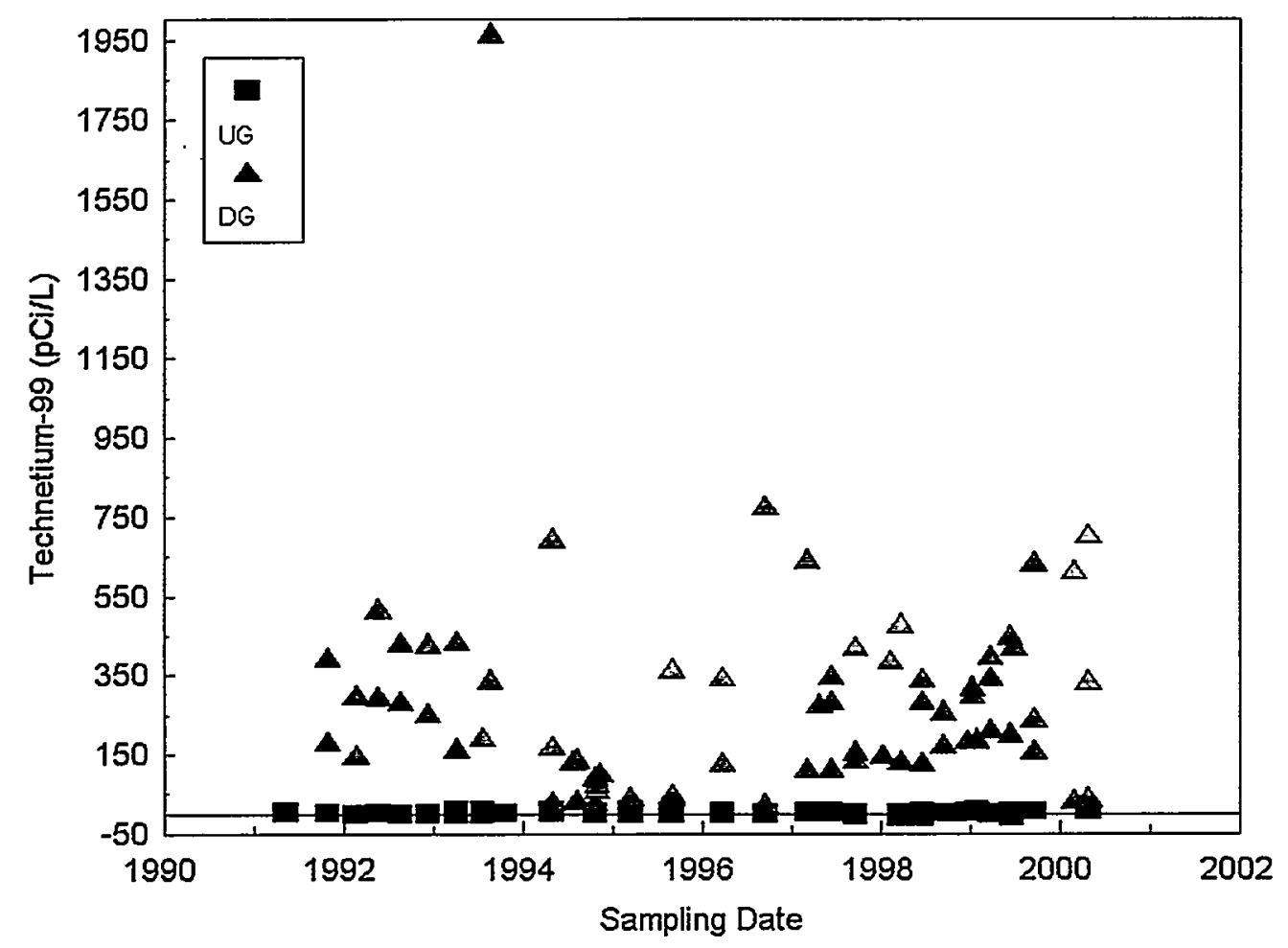

Figure 4.6. Plot of Technetium-99 (detects and nondetects) in Upgradient Wells 299-W18-25 and 299-W18-31 and Downgradient Wells 299-W19-31, 299-W19-32, 299-W19-41, and 299-W19-42. Note: During the period of groundwater flow reversal (1993 - 1995) wells 299-W18-25 an 299-W18-31 were downgradient to the WMA. 
It is interesting to note that although technetium-99 in the downgradient well group reached a minimum in 1994-95, similar, but slightly later to that exhibited by nitrate, there is no corresponding increase in the upgradient wells. It is reasonable to expect that any tank waste reaching groundwater would be a source of both nitrate and technetium-99. The usual assumption is that technetium-99, present as an anion (pertechnetate), is transported at the same rate as nitrate. If, however, technetium-99 is retarded (small $\mathrm{K}_{\mathrm{d}}$ ) relative to nitrate, the discrepancy may be explained. In this case the technetium-99, lagging slightly behind the nitrate pulse, would not reach the upgradient wells before the effects of the 216-U-14 ditch discharges ended and groundwater flow returned to a more easterly direction.

\subsubsection{Chromium}

Chromium, present in tank waste in the soluble hexavalent form, is a frequent co-contaminant with technetium-99 in Hanford groundwater. Chromium (filtered) has been present in detectable quantities in both upgradient wells (Figure 4.7a) and downgradient wells (Figure 4.7b) at WMA U; however, it has generally been higher in downgradient wells, especially in downgradient well 299-W19-32. Pre-1994 chromium concentrations for upgradient wells are not plotted on Figure $4.7 \mathrm{a}$ because all are below detection.

The July 1993 chromium high ( $100 \mu \mathrm{g} / \mathrm{L})$ in well 299-W19-32 corresponds to the technetium-99 high in that well. Technetium-99 concentrations are not available for samplings that indicated high chromium values for well 299-W19-32 in July 1994 and December 1997. However, these high chromium concentrations correspond to elevated concentrations of iron and are probably related to corrosion within the well rather than groundwater contamination. The increase in chromium in replacement well 299W19-41 correlates with the increasing technetium-99 in that well; however, both are well below the maximum contaminant level, and a well defined trend is not evident.

Starting early in 1998, chromium concentrations in upgradient well 299-W18-25 began to increase. The chromium increase in this well is associated with increasing iron, manganese, and nickel. However, this is not the case for downgradient well 299-W19-41 (Figure 4.8). Well 299-W18-25 is nearly dry and the most likely source of chromium in this case is the corrosion of stainless steel. The observed corrosion products could represent material that has accumulated near the bottom of the well over its operational life as a result of slow corrosion of the stainless steel screen, or it may be the result of corrosion of construction debris left in the well after construction. Apparently in the construction of early RCRA wells at Hanford no attempt was made to keep cuttings, filings, or other debris from completion of the wellhead from falling into the well.

Concentrations of chromium in well 299-W19-41 is well below the maximum contaminant level. There is no indication of an upgradient source for the chromium, and its presence is consistent with the presence of nitrate and technetium-99 in the well. The reason for the apparently exponential decrease in manganese concentrations in well $299-\mathrm{W} 19-41$ is uncertain, but is probably construction related. 

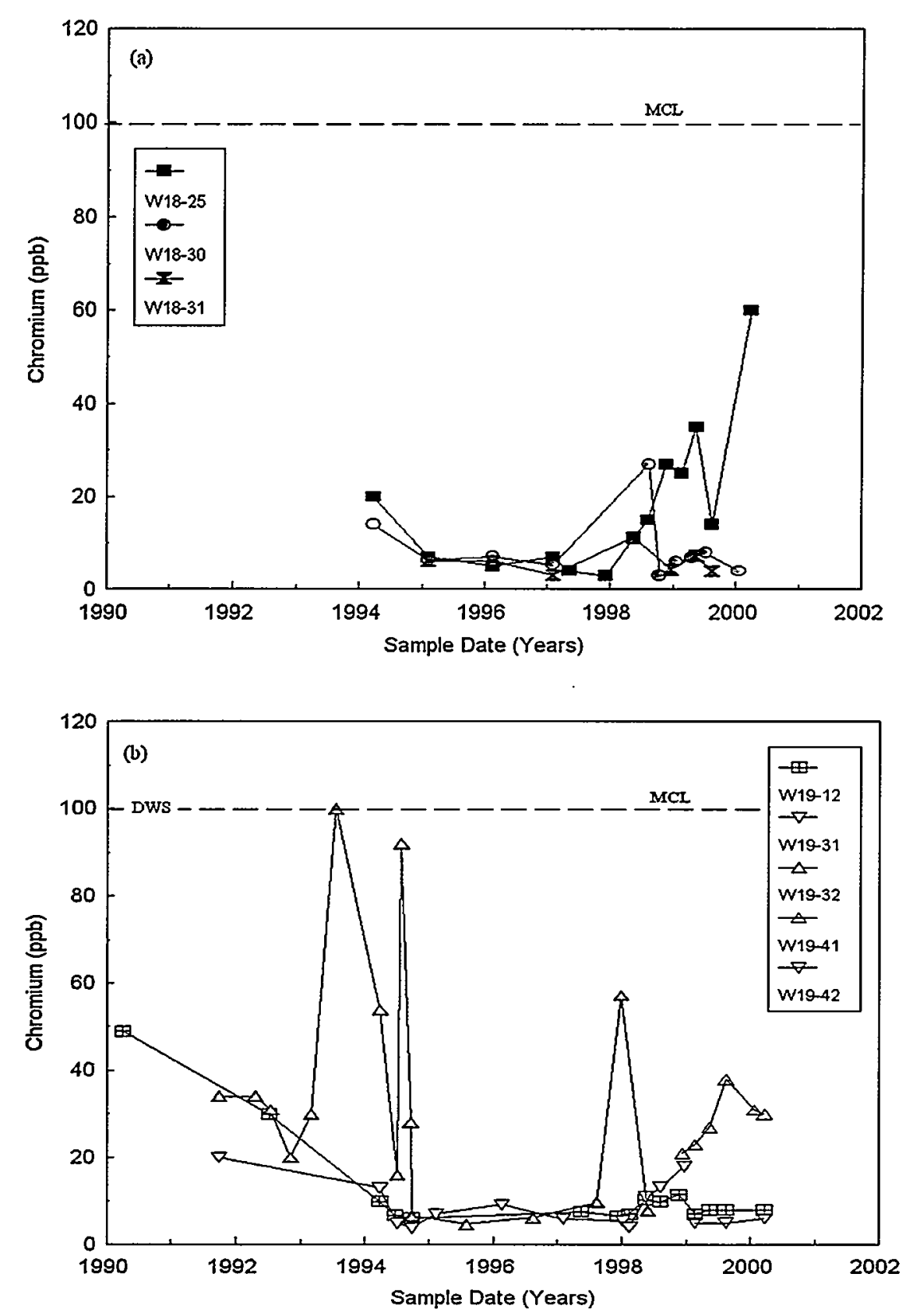

Figure 4.7. Plot of Filtered Chromium Concentrations in (a) Wells 299-W18-25, 299-W18-31, and 299-W18-30, and in (b) Wells 299-W19-12, 299-W19-31, 299-W19-32, 299-W19-41, and 299-W19-42 

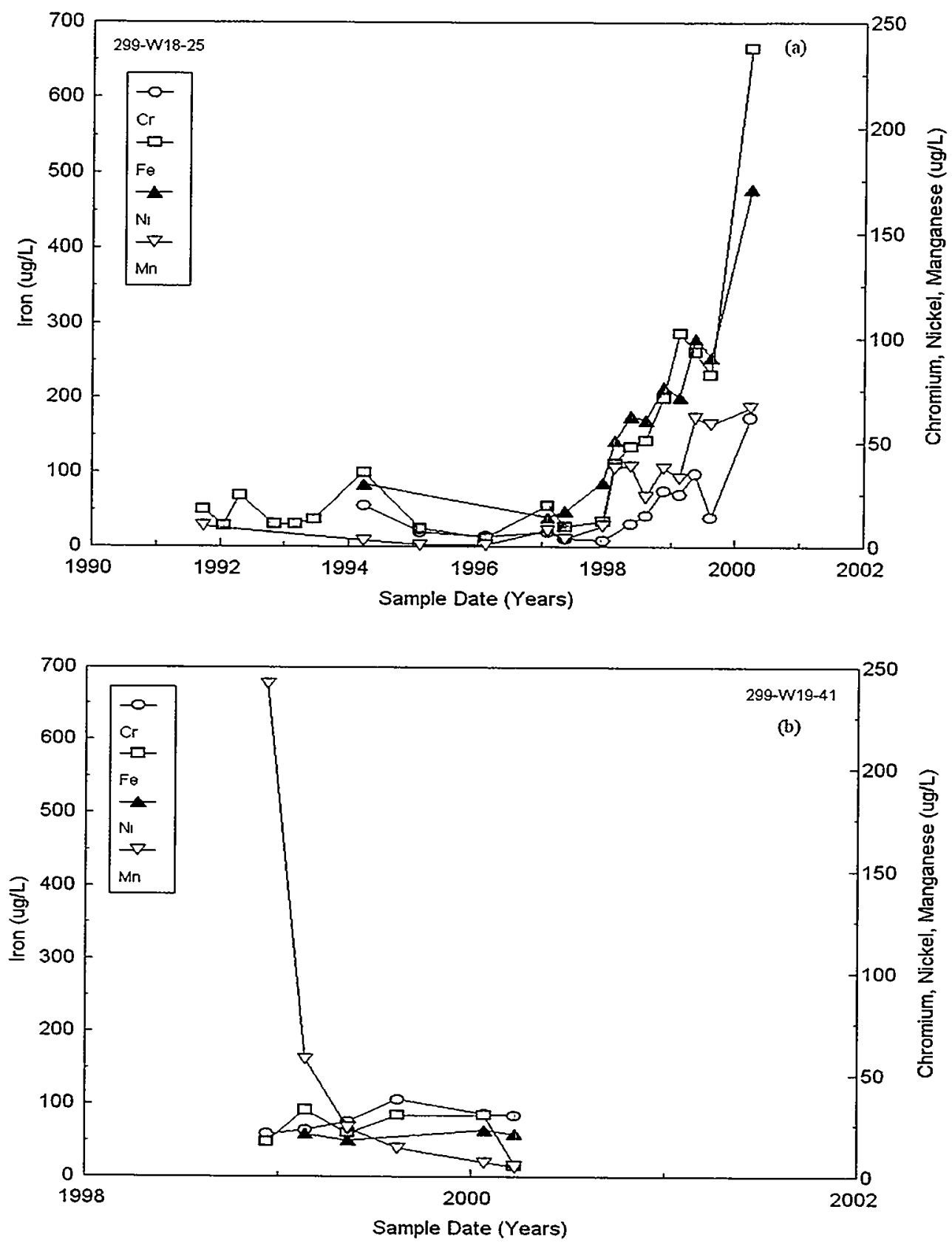

Figure 4.8. Plots of Filtered Iron, Chromium, Nickel, and Manganese in (a) Upgradient Well 299-W18-25, and (b) Downgradient Well 299-W19-41 


\subsubsection{Other Constituents}

Chloride is consistently higher in downgradient well 299-W19-32 than in other wells in the network, including replacement well 299-W19-41 (Figure 4.9a). Patterns of chloride variation in both upgradient and downgradient wells are similar to those observed for nitrate, with downgradient wells 299-W19-31 and 299-W19-32 going through broad minima around 1995 and upgradient wells 299-W18-25 and 299W18-31 going through successive maxima between 1993 and 1996 (Figure 4.9b). Downgradient well 299-W19-32 shows a fairly regular increase in chloride concentrations throughout the monitoring period; however, the sharp decrease in chloride concentrations in replacement well 299-W19-41 indicates that the observed increase in well 299-W19-32 was a result of the declining water table and that the chloride is concentrated near the surface of the aquifer. Chloride is a major contributor to specific conductance in groundwater beneath the southeastern portion of WMA U, and the drop in specific conductance between wells 299-W19-32 and 299-W19-41 (see Figure 4.3) is very similar to the drop in chloride concentrations between the two wells.

Sodium generally has higher concentrations in downgradient wells 299-W19-31 and 299-W19-32; however, not to the extent exhibited by chloride. Sodium concentrations in well 299-W19-32 go through a broad maxima, peaking in late 1994 (Figure 4.10a). Sodium concentrations in other network wells seem to show little systematic variation Figures $4.10 \mathrm{a}$ and $\mathrm{b}$ ).

Calcium concentrations are higher in downgradient wells 299-W19-31 and 299-W19-32, and exhibit patterns very similar to those of sodium, with concentrations in well 299-W19-32 passing through a broad maxima in 1993 to 1996 (Figure 3.11a). Calcium concentrations in wells 299-W18-25, 299-W18-30, and 299-W18-31 all pass through distinct maxima in 1994-1995 (Figure 3.11b). The maxima for wells 299W18-30 and 299-W18-31 occur at approximately the same time, and the data is consistent with the maxima for well 299-W18-25 occurring several months earlier.

Sulfate concentrations are generally higher in downgradient wells 299-W19-31 and 299-W19-32 (Figure 2.12a); however, sulfate concentration peaks in wells 299-W18-25 and 299-W18-31 in late 1993 and early 1994 reached concentrations comparable to those of the downgradient wells (Figure 2.12b). Sulfate peaked in succession in wells 299-W18-25, 299-W18-31, and 299-W18-30. The early 1995 peak in well 299-W18-30 reached concentrations much lower than those in the two upgradient wells.

The behavior of calcium, chloride, sodium, and sulfate are similar to each other and to the behavior of nitrate and technetium-99; however, the peaks for calcium, chloride, sodium, and sulfate are broader and more diffuse than those for nitrate and technetium-99. This difference may indicate a smaller source area for nitrate and technetium-99. The higher chloride in well 299-W19-32 may indicate the infiltration of road salt $(\mathrm{NaCl})$ beneath low areas along the south side of $16^{\text {th }}$ Street along the southern margin of WMA U. 

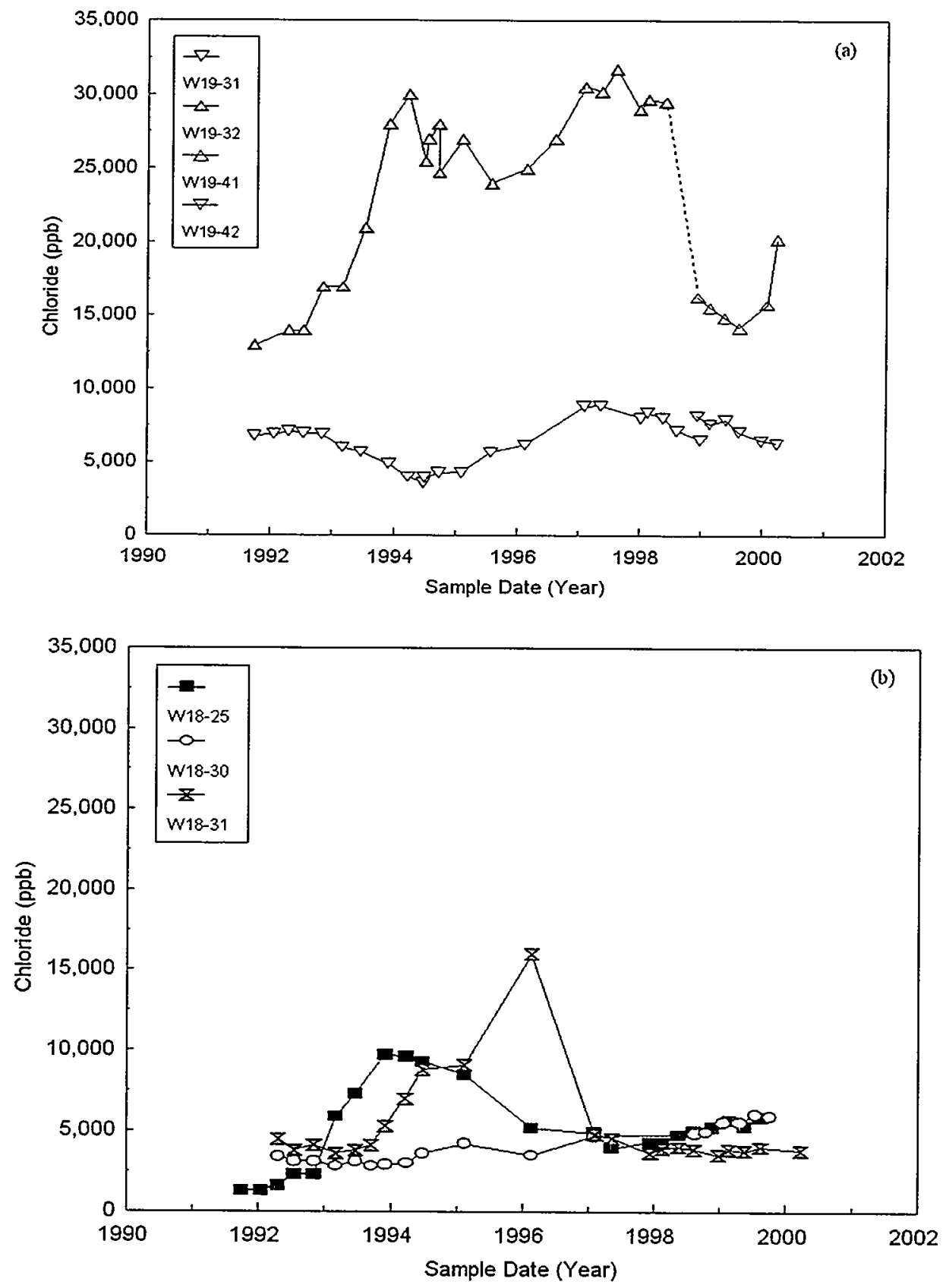

Figure 4.9. Chloride Concentrations in (a) Wells 299-W19-31, 299-W19-32, 299-W19-41, and 299-W19-42; and in (b) Wells 299-W18-25, 299-W18-31, and 299-W18-30 

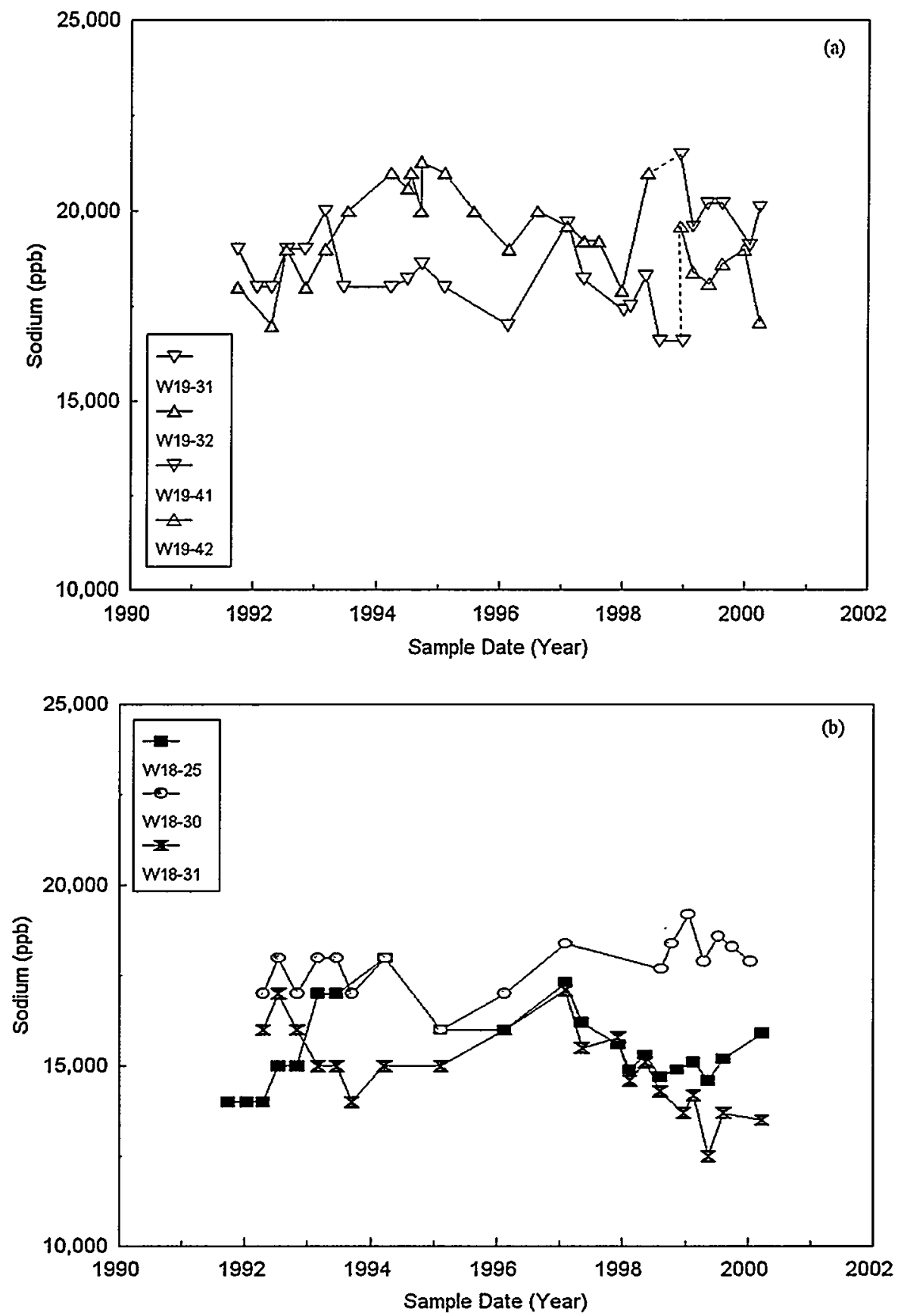

Figure 4.10. Sodium Concentrations in (a) Wells 299-W19-31, 299-W19-32, 299-W19-41, and 299-W19-42; and in (b) Wells 299-W18-25, 299-W18-31, and 299-W18-30 

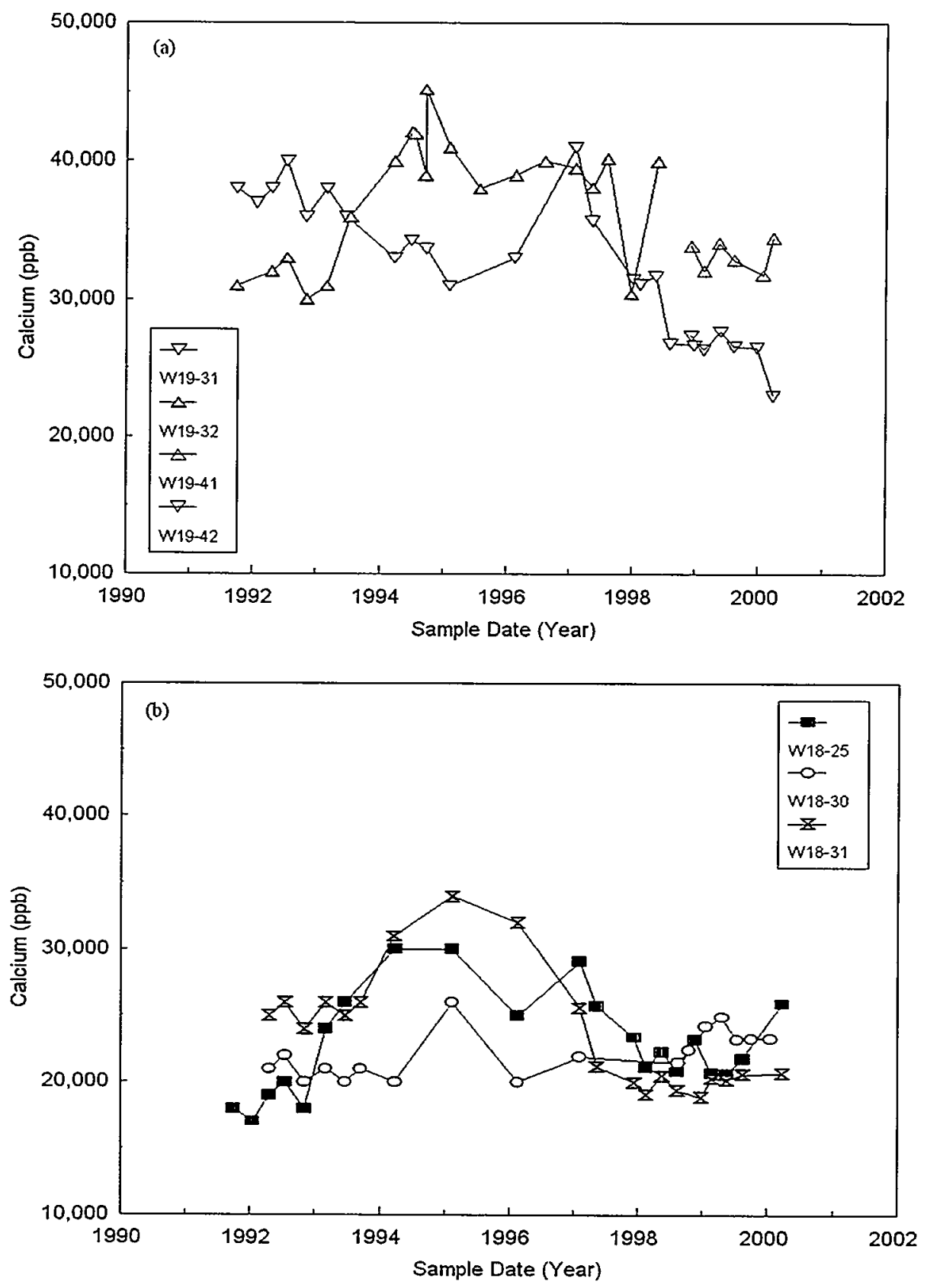

Figure 4.11. Calcium Concentrations in (a) Wells 299-W19-31, 299-W19-32, 299-W19-41, and 299-W19-42; and in (b) Wells 299-W18-25, 299-W18-31, and 299-W18-30 

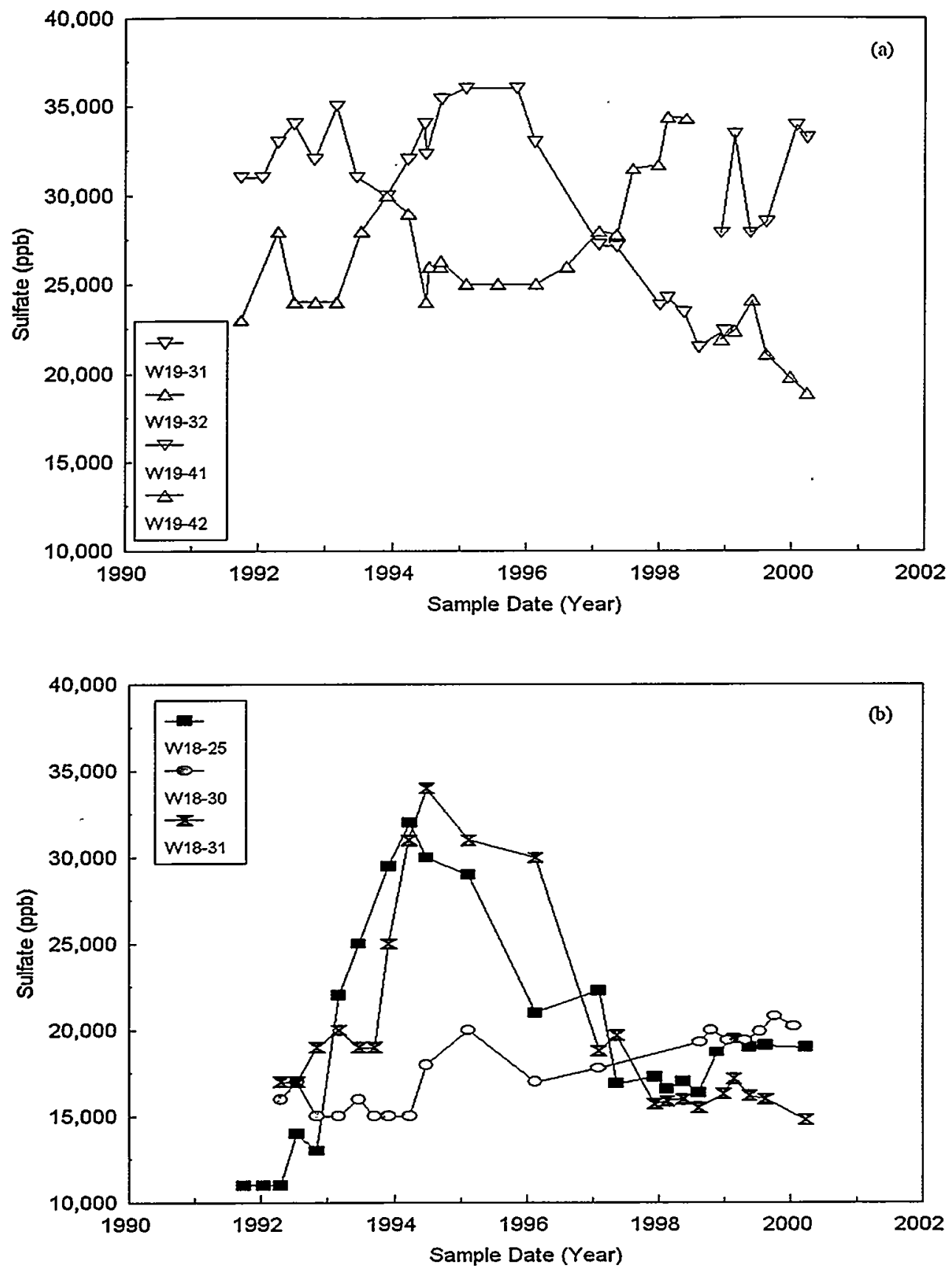

Figure 4.12. Sulfate Concentrations in (a) Wells 299-W19-31, 299-W19-32, 299-W19-41, and 299-W19-42; and in (b) Wells 299-W18-25, 299-W18-31, and 299-W18-30 


\subsection{Conceptual Model}

Conceptual models are essentially collections of working hypotheses that provide a framework for ongoing work. The framework should be continually modified as new data become available and new understanding is developed.

Figure 5.1, taken from Johnson and Chou (1998), is a reasonable representation of pathways to groundwater in the 200 West Area. Sources of contamination include tank leaks, tank overflows, junction box or transfer line leaks. Four tanks within WMA U are known or suspected to be leaking and four other unplanned releases of contamination have been reported. DOE (1997) reported evidence for other, unreported releases and significant quantities of radionuclides within the vadose zone in several parts of the WMA. Thus, if a driving force exists there is contamination available for transport to the water table.

In the tank farms, waste is driven through the vadose zone principally by

- the volume and density of released waste

- gravel enhanced infiltration of normal precipitation (Gee et al. 1992)

- the potential effects of flooding during rapid snow melt events (Hodges 1998, Figure 3.23)

- leaking water lines within or adjacent to the WMA.

Anecdotal evidence indicates that a low area in the road south of WMA U may flood when there is heavy rainfall or rapid snow melt, covering the southern margin of the WMA. Tank farm workers have mentioned "spongy" ground along the south side of the tank farm. A water line runs along the south side of the WMA; however, whether it has leaked or not is uncertain. In addition, a low area east of Camden Avenue, along the south side of $16^{\text {th }}$ Street, may collect water and affect groundwater near the southeast corner of WMA U. If impounded surface water and possibly leaking water lines in the southern portion of the WMA provided a greater driving force for infiltration this could explain the deeper penetration of contaminants in this area reported by DOE (1997) and the apparent source of nitrate and technetium- 99 in this area.

In many parts of the 200 West Area any mobile constituents that have reached the water table have probably done so through specific pathways such as clastic dikes or unsealed boreholes. The situation in most of the 200 West Area is complicated by the caliche layer, which may cause waste to reach groundwater some distance from the actual leak as fluids will migrate along its top until a downward pathway is found, as noted by Schalla (1982). However, Singleton and Lindsey (1994) note that in the area immediately south of WMA U, the caliche layer is highly fractured, and would not provide a significant barrier to downward fluid transport. An additional complicating factor is the presence of thin, discontinuous silt layers within the Hanford formation that tend to act as flow barriers and produce lateral transport within the vadose zone. 


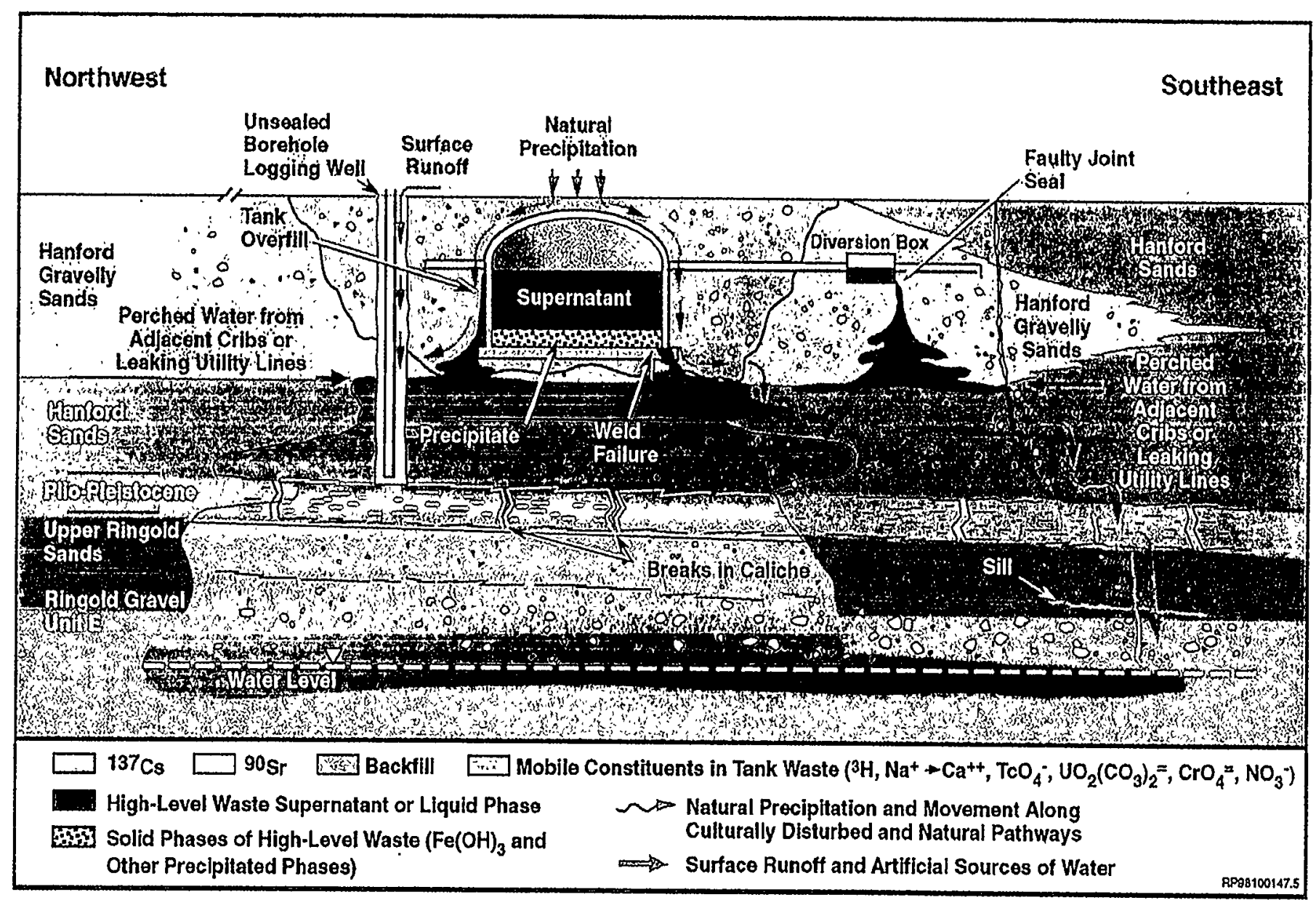

Figure 4.1. Soil Pathway Conceptual Model. Purple depicts tank waste and leakage during early operations in the 1960 s. Subsequent, hypothetical, movement of contaminants through the vadose zone, shown in red, yellow, and green, covers a time period from early operations to the present. As a result of volume reduction measures, a much smaller volume of free liquid remains in the tanks today. Depth to

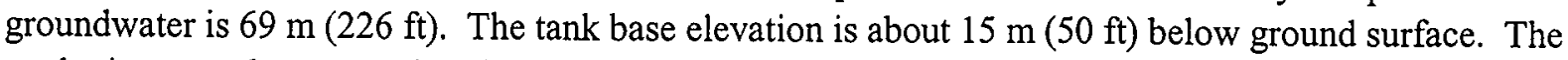
geologic strata shown are simplified for illustration purposes. (From Johnson and Chou [1998]) 
If and when waste reaches the water table, it may sink or form a layer at the top of the aquifer depending upon the density of the waste and its arrival rate at the water table, relative to the rate of groundwater flow. Hanford tank waste is essentially a saturated sodium nitrate brine, and its density is sufficient to allow it to sink through the aquifer if flow rate is too low to facilitate mixing. Waste mobilized by influx of meteoric or other surface water will be diluted and the density will depend on the degree of mixing. An additional complication is relatively clean water that may infiltrate to the water table upgradient and/or downgradient of the point where the contaminants entered groundwater, an effect enhanced by wide gravel aprons around the tanks. Thus, there may be vertical layering in the aquifer resulting from multiple infiltration effects. Determination of the vertical variation of contaminants within the aquifer may aid in determining vadose zone transport mechanisms within the tank farms.

The direction of groundwater flow in the vicinity of WMA $U$ has varied because of changing effluent discharge sites within the 200 West Area (Hodges 1998). The direction of groundwater flow, at the time when the RCRA detection network was established, was toward the northeast (Caggiano and Goodwin 1991). However, with the closure of U Pond and continued discharge at Plutonium Finishing Plant, the direction of groundwater flow changed to an easterly and then southeasterly direction. The groundwater flow system was perturbed by effluent discharges to the 216-U-14 ditch in $1991-1993$. As a result, the direction of groundwater flow reversed and was toward the northeast from 1993 to 1996 . As the direction of groundwater flow returned to its pre-discharge direction in 1997, Phase 3 of the 200-ZP-1 pump-andtreat activity started (DOE 2000). As a result of the pump-and-treat activity, the direction of groundwater flow assumed its present east to northeast to northerly direction (see Figure 3.4). Another complication is highly variable cementation within the Ringold Formation. Thus, locally, there may be preferred flow paths that differ from the general flow direction indicated by the water-table maps.

Groundwater chemistry data presented in Section 4 indicate that the source of chromium, nitrate, and technetium-99 detected in downgradient wells is within WMA $U$ and is not the result of an upgradient source. In addition, variation of concentrations with the changing direction of groundwater flow indicates a source within the southern portion of the WMA. Ratios of mobile contaminants (e.g., chromium, nitrate, technetium-99, tritium) are useful in identifying tank waste components and mixing trends in groundwater (Johnson and Chou 1998; Hodges 1998). Plots of nitrate/technetium-99 versus technetium99 (Figure 5.2) indicate that the data is consistent with the observed groundwater contamination being the result of mobilization and dilution of tank waste by infiltrating surface water. Groundwater samples from WMA U plot in a band that extends from near " $A$ " downward and to the right to points near " $B$ " and "C." Upgradient wells 299-W18-25 and 299-W18-31 have low technetium-99 concentrations and high ratios, plotting near "A." Downgradient wells 299-W19-12, 299-W19-31, 299-W19-32, 299-W19-41, and 299W19-42 plot nearer to " $C$ " and " $D$," representing higher technetium-99 and a lower ratio. In a plot of this type, lines $\mathrm{AB}$ and $\mathrm{AC}$ represent mixing lines between a groundwater composition near " $\mathrm{A}$ " and groundwater compositions near "C" and " $\mathrm{D}$." The arrow marked " $\mathrm{D}$ " represents the dilution of a hypothetical tank waste composition by infiltrating surface water. Along " $D$ " technetium- 99 decreases with increasing degrees of dilution; however, the technetium-99/nitrate ratio remains unchanged. Thus, lines $\mathrm{AC}$ and $\mathrm{AD}$ represent mixing lines between an ambient, upgradient composition and infiltrating surface water contaminated with varying amounts of tank waste. The tank compositions shown on Figure 5.2 are estimates of current bulk compositions for the four leaking tanks from Agnew (1997). Other tank compositions in WMA U are similar to the four shown. 


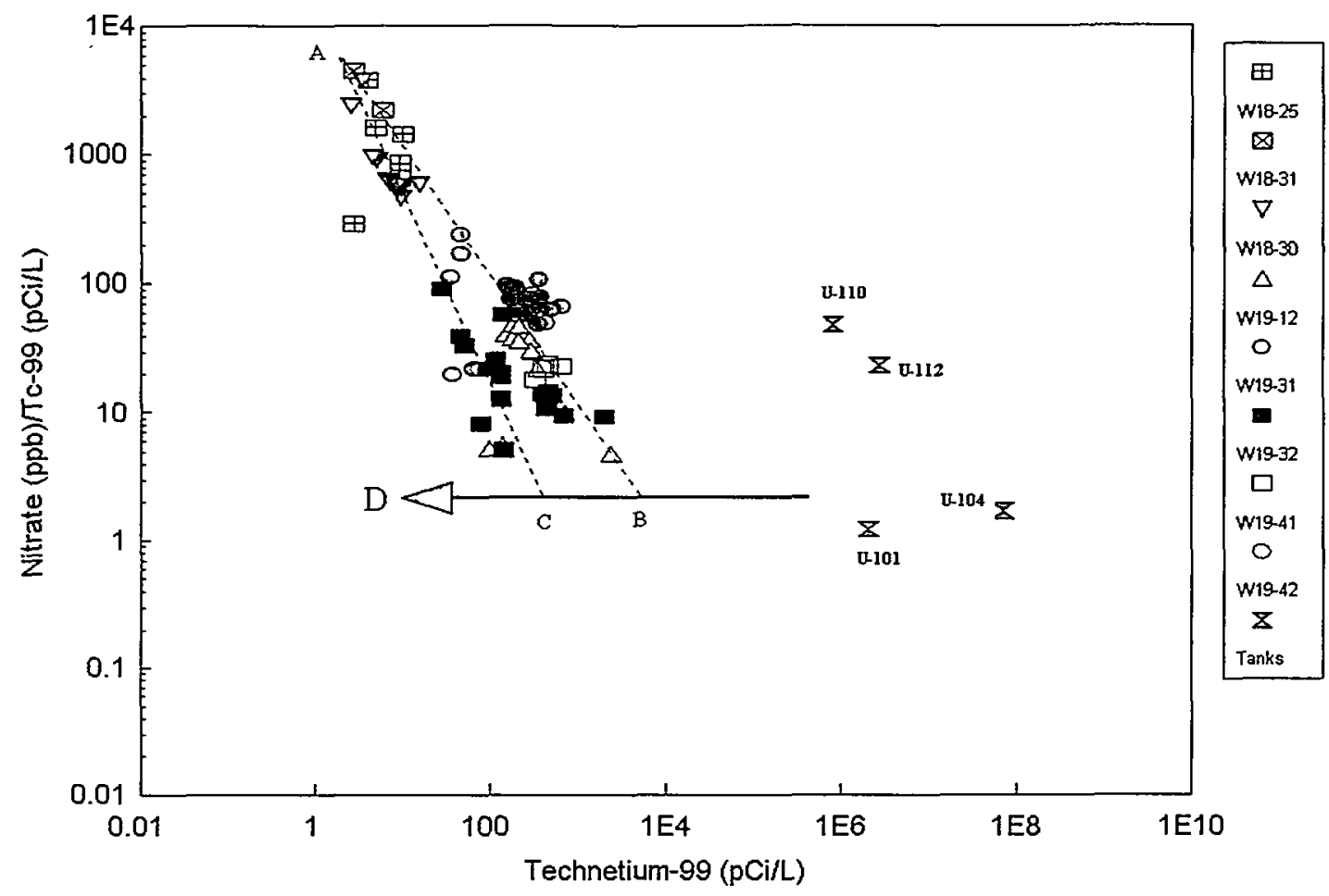

Figure 5.2. Plot of Nitrate/Technetium- 99 versus Technetium- 99 for Monitoring Wells at WMA U. Arrow " $D$ " represents dilution path for mobilization of tank waste by infiltrating surface water. Tank compositions are from Agnew (1997).

The conceptual model that best fits the existing data has an area of enhanced surface water infiltration in the southern portion of the WMA. Water moving downward through the paleosols of the PlioPleistocene unit would mobilize calcium and sulfate, and potentially small quantities of sodium chloride. Somewhere within this zone of enhanced infiltration the infiltrating water contacts tank waste and mobilizes the more mobile constituents, principally chromium, nitrate, and technetium-99. A location near the southern end of the WMA is consistent with the contaminant pattern during the groundwater flow reversal, with the contaminants being pushed away from the downgradient wells (299-W19-31 and 299W19-32) and arriving in a general south to north sequence at the upgradient wells and well 299-W18-30. It is also consistent with the contaminant patterns in downgradient wells as groundwater assumed a more easterly flow direction after 1994. The consistently higher chloride concentrations in well 299-W19-32 seems to be a local effect and may be a result of road salt infiltration in the low areas along the south side of $16^{\text {th }}$ Street, directly across from this well. 


\subsection{Conclusions}

The elevated specific conductance in downgradient well 299-W19-41 is a result of nonhazardous constituents, principally bicarbonate, calcium, chloride, magnesium, sodium, and sulfate leached from the vadose by infiltrating surface water in the southern part of WMA U.

There is no evidence for upgradient sources of chromium and technetium-99 at WMA U. There is an upgradient component for nitrate; however, it cannot explain all nitrate observed in downgradient wells at the WMA. Tank waste constituents chromium, nitrate, and technetium-99, present in groundwater in WMA $U$ in relatively low concentrations, are most likely the result of mobilization of tank waste at the WMA by infiltrating surface waters. The source of the contaminants is apparently in the southern portion of the WMA. 


\subsection{References}

40 CFR 265. "Interim Status Standards for Owners and Operators of Hazardous Waste Treatment, Storage, and Disposal Facilities." Code of Federal Regulations.

Agnew, S. F. 1997. Hanford Tank Chemical and Radionuclide Inventories: HDW Model Rev. 4. LA-UR-96-3860, Los Alamos National Laboratory, Los Alamos, New Mexico.

Anderson, J. D. 1990. A History of the 200 Area Tank Farms. WHC-MR-0132, Westinghouse Hanford Company, Richland, Washington.

Baker, V. R., B. N. Bjornstad, A. J. Busacca, K. R. Fecht, E. P. Kiver, U. L. Moody, J. G. Rigby, D. F. Stradling, and A. M. Tallman. 1991. "Quaternary Geology of the Columbia Plateau." In Quaternary Nonglacial Geology; Conterminous U. S., R. B. Morrison (ed.), The Geological of Society America, Vol. K-2, pp. 215-250, Boulder, Colorado.

Caggiano, J. A. 1994. "Single-Shell Tanks." In Annual Report for RCRA Groundwater Monitoring Projects at Hanford Site Facilities for 1993, DOE/RL-93-88, pp. 4.13-1 through 4.13-50, prepared by Geoscienses Group, Westinghouse Hanford Company, Environmental Division for U.S. Department of Energy, Richland Operations Office, Richland, Washington.

Caggiano, J. A., and Goodwin. 1991. Interim Status Groundwater Monitoring Plan for the-Single-Shell Tanks. WHC-SD-EN-AP-012, Rev. 1, Westinghouse Hanford Company, Richland, Washington.

Chou. 1998. "Statistics" in Hanford Site Groundwater Monitoring for Fiscal Year 1997, M. J. Hartman (ed.). PNNL-11793, Appendix B, Pacific Northwest National Laboratory, Richland, Washington.

Fecht, K. R., S. P. Reidel, and A. M. Tallman. 1987. "Paleodrainage of the Columbia River System on the Columbia Plateau of Washington State-A Summary." In Selected Papers on the Geology of Washington, J. E. Schuster (ed.), Bulletin 77, pp. 219-248, Washington Division of Geology and Earth Resources, Olympia, Washington.

Gee, G. W., M. J. Fayer, M. L. Rockhold, and M. D. Campbell. 1992. "Variations in Recharge at the Hanford Site." Northwest Science 66:237-250.

Graham, M. J., M. D. Hall, S. R. Strait, and W. R. Brown. 1981. Hydrology of the Separations Area. RHO-ST-42, Rockwell Hanford Operations, Richland, Washington.

Hanlon, B. M. 1996. Waste Tank Summary Report for Month Ending September 30, 1996. WHC-EP0182-102, Westinghouse Hanford Company, Richland, Washington.

Hartman, M. J., L. F. Morasch, and W. D. Webber, (eds.). 2000. Hanford Site Groundwater Monitoring for Fiscal Year 1999. PNNL-13116, Pacific Northwest National Laboratory, Richland, Washington. 
Hodges, F. N. 1998. Results of Phase I Groundwater Quality Assessment for Single-Shell Tank Waste Management Areas T and TX-TY at the Hanford Site. PNNL-11809, Pacific Northwest National Laboratory, Richland, Washington.

Hodges, F. N., and C. J. Chou. 2000. Groundwater Quality Assessment Plan for Single-Shell Tank Waste Management Area U at the Hanford Site. PNNL-13185, Pacific Northwest National Laboratory, Richland, Washington.

Horton, D., and F. N. Hodges. 1999. Borehole Data Package for 1998 Wells Installed at Single-Shell Tank Waste Management Area U. PNNL-12126, Pacific Northwest National Laboratory, Richland, Washington.

Johnson, V. G., and C. J. Chou. 1998. Results of Phase I Groundwater Quality Assessment for SingleShell Tank Waste Management Area S-SX at the Hanford Site. PNNL-11810, Pacific Northwest National Laboratory, Richland, Washington.

Kincaid, C. T., M. P. Bergeron, C. R. Cole, M. D. Freshley, N. L. Hassig, V. G. Johnson, D. I. Kaplan, R. J. Serne, G. P. Streile, D. L. Strenge, P. D. Thorne, L. W. Vail, G. A. Whyatt, and S. K. Wurstner. 1998. Composite Analysis for Low-Level Waste Disposal in the 200 Area Plateau of the Hanford Site. PNNL11800, Pacific Northwest National Laboratory, Richland, Washington.

Kupfer, M. J., A. L. Boldt, B. A. Higley, K. M. Hodgson, L. W. Shelton, B. C. Simpson, R. A. Watrous, M. D. LeClair, G. L. Borsheim, R. T. Winward, R. M. Orme, N. G. Colton, S. L. Lambert, D. E. Place, and W. W. Schulz. 1999. Standard Inventories of Chemicals and Radionuclides in Hanford Tank Waste. HNF-SD-WM-TI-740, Rev. 1, Lockheed Martin Hanford Corporation, Richland, Washington.

Lindsey, K. A. 1995. Miocene- to Pliocene-Aged Suprabasalt Sediments of the Hanford Site, SouthCentral Washington. BHI-00184, Bechtel Hanford, Inc., Richland, Washington.

Resource Conservation and Recovery Act of 1976, as amended, Public Law 94-580, 90 Stat. 2795, 42 USC 6901 et seq.

Schalla, R. 1982. Flow Path Deflection and Migration Rates of TNT and RDX Contaminants in an Alluvial Aquifer. ADPA 12th Symposium, Langley AFB, Virginia, BN-SA-1474, Pacific Northwest Laboratory, Richland, Washington.

Singleton, K. M., and K. A. Lindsey. 1994. Groundwater Impact Assessment Report for the 216-U-14 Ditch. WHC-EP-0698, Westinghouse Hanford Company, Richland, Washington.

U.S. Department of Energy. 1988. Consultation Draft, Site Characterization Plan, Reference Repository Location. DOE/RW-0164, Vols. 1-9, Office of Civilian Radioactive Waste Management, Washington, D.C. 
U.S. Department of Energy. 1989. Single-Shell Tank Closure/Correction Action Work Plan. DOE/RL89-16, Richland Operations Office, Richland Washington.

U.S. Department of Energy. 1992. U-Plant Source Aggregate Area Management Area Study (AAMSR). DOE/RL-91-52, Richland Operations Office, Richland, Washington.

U.S. Department of Energy. 1997. Vadose Zone Characterization Project at the Hanford Tank Farms U Tank Farm Report. GJO-97-1-TAR, GJO-HAN-8, Albuquerque Operations Office and Grand Junction Office, Grand Junction, Colorado.

U.S. Department of Energy. 2000. Fiscal Year 1999 Annual Report for the 200-UP-1, 200-ZP-1, and 100-NR-2 Pump and Treat Operations and Operable Units. DOE/RL-99-79, Richland Operations Office, Richland, Washington.

Washington Administrative Code, 173-303-400. Interim Status Facility Standards. Olympia, Washington.

Washington Administrative Code, 173-303-610. Closure and Postclosure. Olympia, Washington.

Washington State Department of Ecology, U.S. Environmental Protection Agency, and U.S. Department of Energy. 1998. Hanford Federal Facility Agreement and Consent Order. Document No. 89-10, Rev. 5 (The Tri-Party Agreement) Olympia, Washington. 


\section{Distribution}

No. of

Copies

\section{OFFSITE}

C. Abraham

U.S. General Accounting Office

825 Jadwin Ave., MSIN \#A1-80

Richland, WA 99352

2 Confederated Tribes and Bands of the

Yakama Indian Nation

Environmental Restoration Waste

Management Program

2802 Main Street

Union Gap, WA 98903

ATTN: W. Riggsbee

R. Jim

2 Confederated Tribes of the Umatilla Indian

Reservation

P.O. Box 638

Pendleton, OR 97801

ATTN: W. Burke

$$
\text { T. Gilmore }
$$

T. French

Savannah River Site

Aiken, SC 29802

2 Nez Perce Tribe

Nez Perce Tribal Department of

Environmental Restoration and Waste

Management

P.O. Box 365

Lapwai, ID 83540

ATTN: D. Powaukee

S. Sobczyk
No. of

Copies

Oregon Water Resources

Water Resources Department

555 13th Street Northeast

Salem, OR 97301

G. Pollet

Heart of America Northwest

1305 4th Ave., Suite 208

Seattle, WA 98101

S. Van Verst

Washington State Department of Health

Airdustrial Park, Bldg. 5

Olympia, WA 98504

\section{ONSITE}

17 DOE

C. E. Clark

A5-15

M. J. Furman (7)

A5-16

J. B. Hall

A5-15

R. D. Hildebrand

A5-13

R. W. Lober

S7-51

E. M. Mattlin

A5-15

J. K. McClusky

S7-54

E. J. Rasmussen

A5-58

K. M. Thompson

A5-13

R. M. Yasek

H6-60

Public Reading Room

H2-53

\section{Bechtel Hanford, Inc.}

B. H. Ford

HO-02

G. B. Mitchem

H0-21

Distr.1 
No. of

\section{Copies}

15 CH2M HULL

D. I. Allen

J. V. Borghese (5)

R. J. Brown

C. B. Bryan

W. T. Dixon

B. G. Erlandson

A. J. Knepp

D. A. Myers

M. J. Reiss

G. D. Wittreich

R. D. Wojtasek

Jacobs Engineering Group

P. M. Rogers

H0-22

2 MACTEC-ERS

J. F. Bertsch

R. G. McCain

B1-42

B1-42

U.S. Environmental Protection Agency

D. A. Faulk

B5-01

6 Washington State Department of Ecology

S. L. Dahl

B5-18

D. N. Goswami

A. D. Huckaby

S. Leja

B5-18

S. McKinney (Olympia)

A. Valero

B5-18

B5-18

B5-18

B5-18
No. of

Copies

2 Waste Management Federal Services, Inc.

J. C. Sonnichsen

H6-26

M. I. Wood

H6-06

Duratek

M. G. Gardner

H1-11

35 Pacific Northwest National Laboratory

C. J. Chou

K6-81

P. E. Dresel

K6-96

G. W. Gee

K9-33

M. J. Hartman

K6-96

F. N. Hodges (10)

K6-81

D. G. Horton

K6-81

V. G. Johnson

K6-96

S. P. Luttrell (5)

K6-96

R. B. Mercer

K6-96

S. M. Narbutovskih

K6-96

S. P. Reidel

K6-81

R. Schalla

K6-96

R. J. Serne

K6-81

M. D. Sweeney

K6-81

B. A. Williams

K6-81

Information Release Office (7)

K1 $1-06$ 